\title{
Application of the RESRAD Computer Code to VAMP Scenario S
}

Environmental Assessment Division Argonne National Laboratory 


\section{Argonne National Laboratory}

Argonne National Laboratory, with facilities in the states of Illinois and Idaho, is owned by the United States Government, and operated by the University of Chicago under the provisions of a contract with the Department of Energy.

This technical memo is a product of Argonne's Environmental Assessment Division (EAD). For information on the division's scientific and engineering activities, contact:

Director, Environmental Assessment Division

Argonne National Laboratory

Argonne, Illinois 60439-4815

Telephone (630) 252-3107

Presented in this technical memo are preliminary results of ongoing work or work that is more limited in scope and depth than that described in formal reports issued by the EAD.

Publishing support services were provided by Argonne's information and Publishing Division (for more information, see IPD's home page: http://www.ipd.anl.gov/).

\section{Disclaimer}

This report was prepared as an account of work sponsored by an agency of the United States Government. Neither the United States Government nor any agency thereof, nor any of their employees, makes any warranty, express or implied, or assumes any legal liability or responsibility for the accuracy, completeness, or usefulness of any information, apparatus, product, or process disclosed, or represents that its use would not infringe privately owned rights. Reference herein to any specific commercial product, process, or service by trade name, trademark, manufacturer, or otherwise, does not necessarily constitute or imply its endorsement, recommendation, or favoring by the United States Government or any agency thereof. The views and opinions of authors expressed herein do not necessarily state or reflect those of the United States Government or any agency thereof.

Avallable to DOE and DOE contractors from the Office of Scientific and Technical Information, P.O. Box 62, Oak Ridge, TN 37831; prices available from (423) 576-8401.

Available to the public from the National Technical Information Service, U.S. Department of Commerce, 5285 Port Royal Road, Springfield, VA 22161. 


\section{Application of the RESRAD Computer Code to VAMP Scenario $\mathbf{S}$}

by E.K. Gnanapragasam and C. Yu

Environmental Assessment Division,

Argonne National Laboratory, 9700 South Cass Avenue, Argonne, Illinois 60439

March 1997

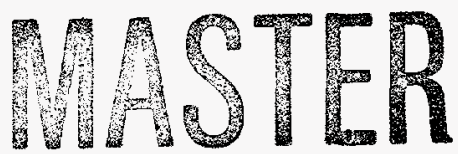

Work sponsored by United States Department of Energy, Office of Environment, Safety and Health 


\section{DISCLAMMER}

Portions of this document may be illegible in electronic image products. Images are produced from the best available original document. 


\section{DISCLAIMER}

This report was prepared as an account of work sponsored by an agency of the United States Government. Neither the United States Government nor any agency thereof, nor any of their employees, make any warranty, express or implied, or assumes any legal liability or responsibility for the accuracy, completeness, or usefulness of any information, apparatus, product, or process disclosed, or represents that its use would not infringe privately owned rights. Reference herein to any specific commercial product, process, or service by trade name, trademark, manufacturer, or otherwise does not necessarily constitute or imply its endorsement, recommendation, or favoring by the United States Government or any agency thereof. The views and opinions of authors expressed herein do not necessarily state or reflect those of the United States Government or any agency thereof. 


\section{CONTENTS}

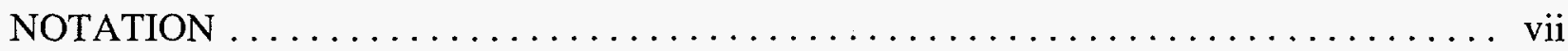

ABSTRACT $\ldots \ldots \ldots \ldots \ldots \ldots \ldots \ldots \ldots \ldots \ldots \ldots \ldots \ldots \ldots \ldots \ldots \ldots$

1 INTRODUCTION $\ldots \ldots \ldots \ldots \ldots \ldots \ldots \ldots \ldots \ldots \ldots \ldots \ldots \ldots \ldots \ldots \ldots \ldots$

2 SCENARIO S DESCRIPTION $\ldots \ldots \ldots \ldots \ldots \ldots \ldots \ldots \ldots \ldots \ldots \ldots \ldots \ldots$

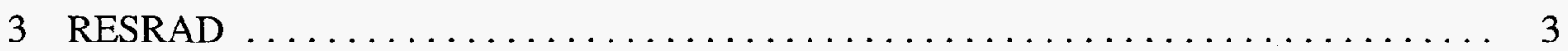

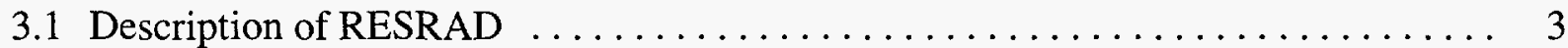

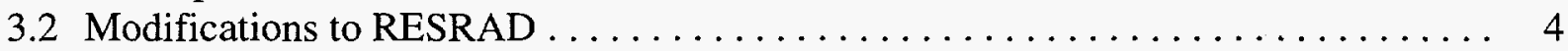

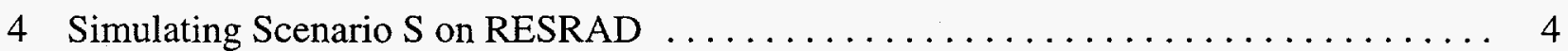

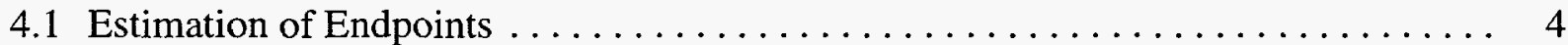

4.2 Estimation of Confidence Interval $\ldots \ldots \ldots \ldots \ldots \ldots \ldots \ldots \ldots \ldots \ldots$

4.3 Inputs Selected for Statistical Study $\ldots \ldots \ldots \ldots \ldots \ldots \ldots \ldots \ldots \ldots \ldots \ldots$

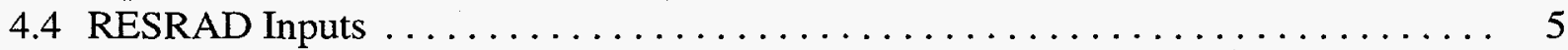

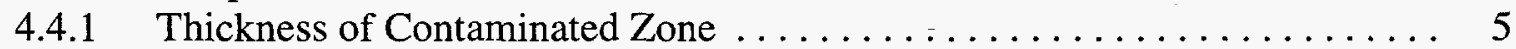

4.4.2 Cesium-137 Content of Contaminated Zone $\ldots \ldots \ldots \ldots \ldots \ldots \ldots \ldots$

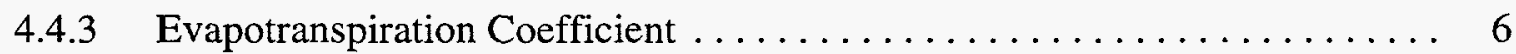

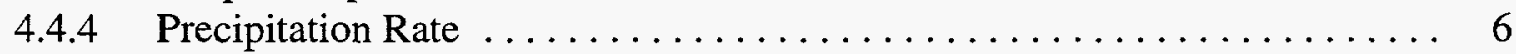

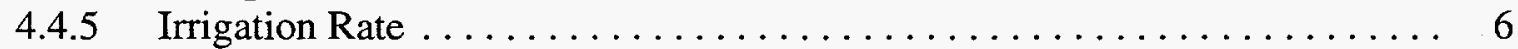

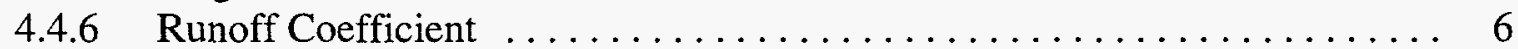

4.4.7 Soil Water Distribution Coefficient of Cesium-137 . . . . . . . . . 7

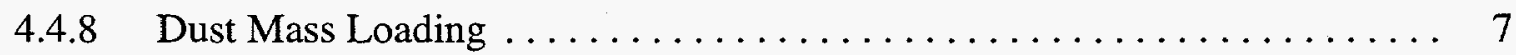

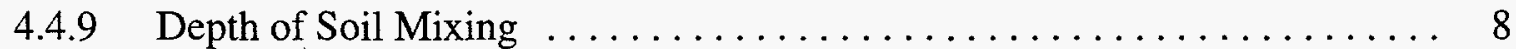

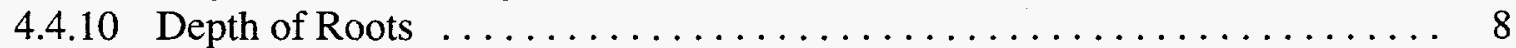

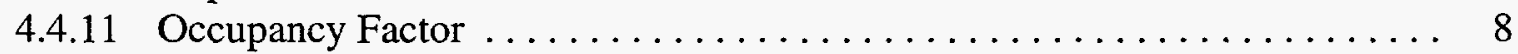

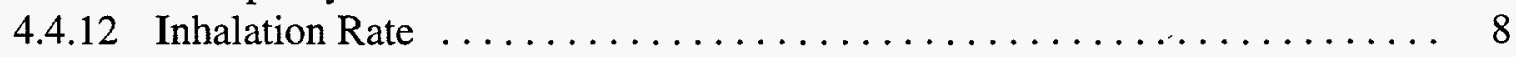

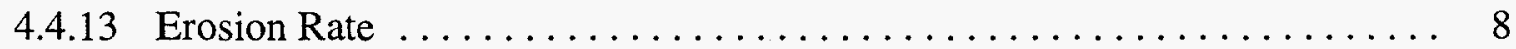

4.4.14 Cesium-137 Content of Surface Water . . . . . . . . . . . . . . . 8

4.4.15 Fraction of Groundwater Usage $\ldots \ldots \ldots \ldots \ldots \ldots \ldots \ldots \ldots \ldots$

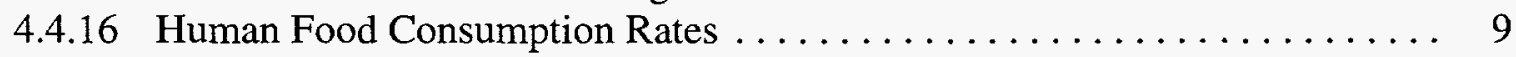

4.4 .17 Livestock Consumption Rates $\ldots \ldots \ldots \ldots \ldots \ldots \ldots \ldots \ldots \ldots \ldots \ldots$

4.4 .18 Soil-to-Plant Root Uptake Factors $\ldots \ldots \ldots \ldots \ldots \ldots \ldots \ldots \ldots \ldots \ldots$

4.4.19 Intake-to-Food Product Transfer Factors $\ldots \ldots \ldots \ldots \ldots \ldots \ldots \ldots \ldots \ldots$

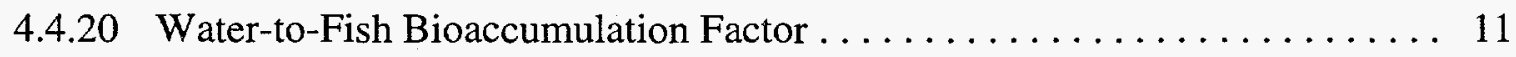

$5 \quad$ RESULTS AND DISCUSSION $\ldots \ldots \ldots \ldots \ldots \ldots \ldots \ldots \ldots \ldots \ldots \ldots \ldots \ldots$

5.1 Comparison of Blind Predictions with Measured or Estimated Values 


\section{CONTENTS (Cont.)}

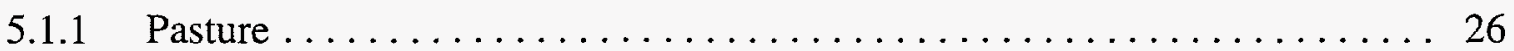

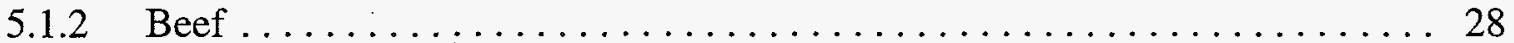

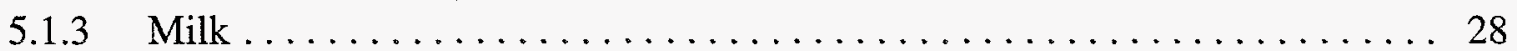

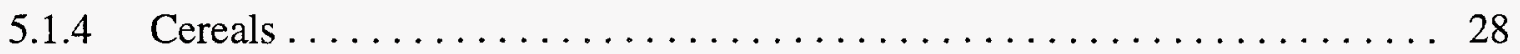

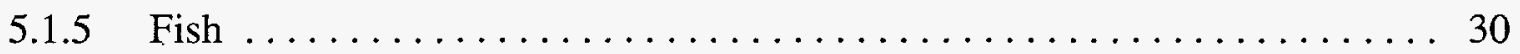

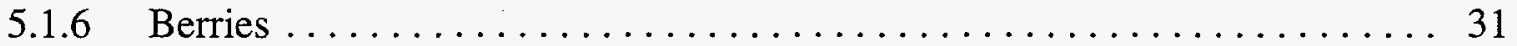

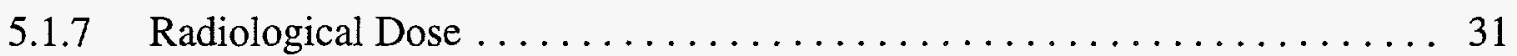

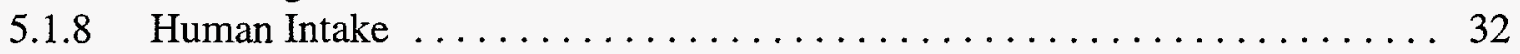

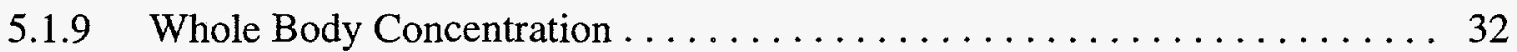

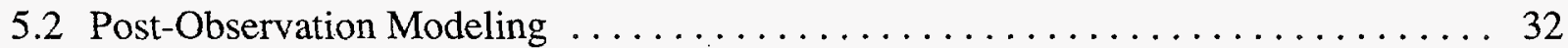

5.3 Suggestions to Extend the Capability of $\operatorname{RESRAD} \ldots \ldots \ldots \ldots \ldots \ldots \ldots$

6 CONCLUSIONS $\ldots \ldots \ldots \ldots \ldots \ldots \ldots \ldots \ldots \ldots \ldots \ldots \ldots \ldots \ldots \ldots \ldots \ldots \ldots$

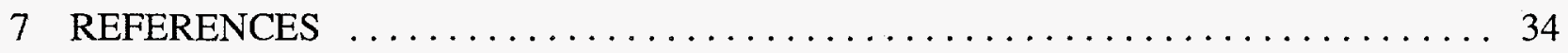

APPENDIX A: Selected Tabular Information from Scenario S Description . . . . . . . 35

APPENDIX B: Calculation of Composite Livestock Feed Intake Rates and

Composite Transfer Factors for the Human Cesium-137 Intake,

Radiological Dose, and Body Burden Runs ............... 47

APPENDIX $\mathrm{C}: \quad$ Calculation of Body Burden $\ldots \ldots \ldots \ldots \ldots \ldots \ldots \ldots \ldots \ldots$

\section{TABLES}

1 Distribution of Depth within Which $95 \%$ of the Cesium-137 in the Surface Soil Is Contained $\ldots \ldots \ldots \ldots \ldots \ldots \ldots \ldots \ldots \ldots \ldots \ldots \ldots \ldots$

2 Cesium-137 in Surface Water Bodies . . . . . . . . . . . . . . 9

3 Human Food Consumption Rates $\ldots \ldots \ldots \ldots \ldots \ldots \ldots \ldots \ldots \ldots \ldots$

$4 \quad$ Livestock Feed Consumption Rates $\ldots \ldots \ldots \ldots \ldots \ldots \ldots \ldots \ldots \ldots \ldots \ldots$

5 Soil-to-Plant Root Uptake Transfer Factors Used in This Study $\ldots \ldots \ldots \ldots \ldots$

6 Intake-to-Animal-Product Transfer Factors Used in This Study $\ldots \ldots \ldots \ldots \ldots$ 


\section{TABLES (Cont.)}

7 Observed Countrywide Average Annual Transfer Factors in Finland 31

A.1 Vertical Distribution of Cesium-137 in Uncultivated Soil at Different Soil Sites ..... 38

A.2 Areal Deposition of Cesium-137 in the Test Region $\ldots \ldots \ldots \ldots \ldots \ldots \ldots \ldots$

A.3 Cesium-137 in Surface Water in Different Drainage Areas and Their Subregions . . . 41

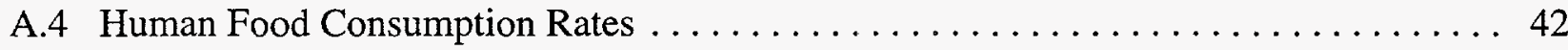

A.5 Feed Utilization of Dairy Cows by the Type of Feed in $1988 \ldots \ldots \ldots \ldots \ldots \ldots 43$

A.6 Feed Utilization of Beef Cattle by the Type of Feed in $1988 \ldots \ldots \ldots \ldots \ldots \ldots \ldots 44$

C.1 Age-Related Body Weight and Effective Half-Life $\ldots \ldots \ldots \ldots \ldots \ldots \ldots$

\section{FIGURES}

1 Cesium-137 Concentration in Air One Meter above Ground Level ............ 7

2 Comparison of Model Predictions of External Dose from Ground Exposure

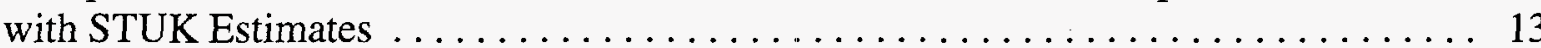

3 Comparison of Model Predictions of Radiological Dose from Ingestion with

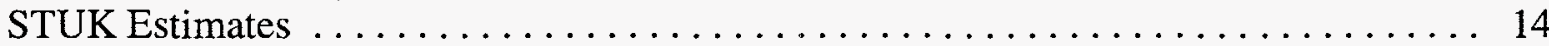

4 Comparison of Model Predictions of Radiological Dose from Inhalation from Resuspension with STUK Estimates $\ldots \ldots \ldots \ldots \ldots \ldots \ldots \ldots \ldots \ldots \ldots$

5 Comparison of RESRAD Predictions of Cesium-137 Content in Barley, Oats, Rye, and Wheat with Measured Values . . . . . . . . . . . . . . 16

6 Comparison of RESRAD Predictions of Cesium-137 Content in Berries, Leafy Vegetables, and Pasture with Measured Values ................ 17

7 Comparison of RESRAD Predictions of Cesium-137 Content in Beef, Milk, Pork, and Fish with Measured Values . . . . . . . . . . . . . . . . . 18

8 Comparison of RESRAD Predictions of Daily Intake of Cesium-137 by Man, Woman, and Child with STUK Estimates 


\section{FIGURES (Cont.)}

9 Comparison of RESRAD Predictions of Whole Body Cesium-137 Burden of

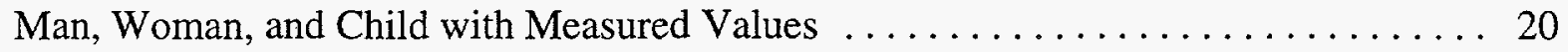

10 Comparison of Revised Model Predictions of External Dose from Ground

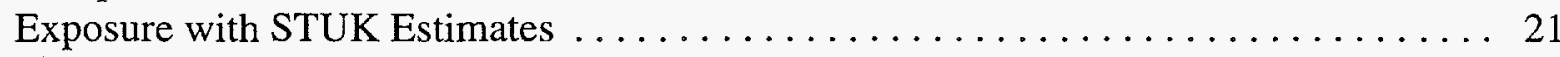

11 Comparison of Revised Model Predictions of Radiological Dose from Ingestion

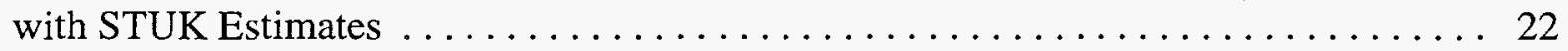

12 Comparison of Revised Model Predictions of Radiological Dose from Inhalation from Resuspension with STUK Estimates $\ldots \ldots \ldots \ldots \ldots \ldots \ldots \ldots \ldots \ldots \ldots$

13 Comparison of Revised RESRAD Predictions of Daily Intake of Cesium-137 by Man, Woman, and Child with STUK Estimates . . . . . . . . . . . . . . 24

14 Comparison of Revised RESRAD Predictions of Whole Body Cesium-137 Burden of Man, Woman, and Child with Measured Values ................... 25

15 Comparison of Revised RESRAD Predictions of Cesium-137 Content in Beef with Measured Values ................................... 26

16 Comparison of Revised RESRAD Predictions of the Distribution of Whole Body Cesium-137 Burden of Man with Measured Values ............... 27

17 Comparison of Observed Cesium-137 Concentrations in Beef with Estimates Based on Beef and Veal Transfer Factors and on Measured and RESRAD Predicted Concentrations in Animal Feed

18 Comparison of Observed Cesium-137 Concentrations in Milk with Estimates Based on Measured and RESRAD Predicted Concentrations in Animal Feed 


\section{Acronyms and Abbreviations}

Cs cesium

EPA U.S. Environmental Protection Agency

IAEA International Atomic Energy Agency

ICRP International Commission on Radiological Protection

LHS Latin hypercube sampling

MPA Multiple Pathways Assessment Working Group

RESRAD Residual Radioactive material guidelines computer code

STUK Finnish Centre for Radiation and Nuclear Safety

VAMP Validation of Environmental Model Predictions

\section{Units of Measure}

$\begin{array}{llll}\mathrm{a} & \text { annum (year) } & \mathrm{kg} & \text { kilogram(s) } \\ \mathrm{Bq} & \text { bequerel(s) } & \mathrm{km} & \text { kilometer(s) } \\ \mathrm{Ci} & \text { curie(s) } & \mathbb{L} & \operatorname{liter}(\mathrm{s}) \\ \mathrm{cm} & \text { centimeter(s) } & \mathrm{m} & \operatorname{meter}(\mathrm{s}) \\ \mathrm{d} & \text { day(s) } & \mathrm{mm} & \text { millimeter(s) } \\ \mathrm{g} & \text { gram(s) } & \mathrm{pCi} & \text { picocurie(s) } \\ \mathrm{kBq} & \text { kilobequerel(s) } & \mathrm{s} & \text { second(s) }\end{array}$




\title{
APPLICATION OF THE RESRAD COMPUTER CODE TO VAMP SCENARIO S
}

\author{
by
}

\author{
E.K. Gnanapragasam and C. Yu
}

\begin{abstract}
The RESRAD computer code developed at Argonne National Laboratory was among 11 models from 11 countries participating in the international Scenario $S$ validation of radiological assessment models with Chernobyl fallout data from southern Finland. The validation test was conducted by the Multiple Pathways Assessment Working Group of the Validation of Environmental Model Predictions (VAMP) program coordinated by the International Atomic Energy Agency. RESRAD was enhanced to provide an output of contaminant concentrations in environmental media and in food products to compare with measured data from southern Finland. Probability distributions for inputs that were judged to be most uncertain were obtained from the literature and from information provided in the scenario description prepared by the Finnish Centre for Radiation and Nuclear Safety. The deterministic version of RESRAD was run repeatedly to generate probability distributions for the required predictions. These predictions were used later to verify the probabilistic RESRAD code. The RESRAD predictions of radionuclide concentrations are compared with measured concentrations in selected food products. The radiological doses predicted by RESRAD are also compared with those estimated by the Finnish Centre for Radiation and Nuclear Safety.
\end{abstract}

\section{INTRODUCTION}

As part of the RESRAD quality assurance/quality control program, the U.S. Department of Energy sponsored Argonne National Laboratory's participation in the international model validation study known as VAMP. VAMP, which stands for Validation of Environmental Model Predictions, is an international program established by the International Atomic Energy Agency (IAEA) in 1988 to use data from the Chernobyl fallout to test and improve biospheric models. Four working groups function within the VAMP program: the Terrestrial Working Group, the Urban 
Working Group, the Aquatic Working Group, and the Multiple Pathways Assessment (MPA) Working Group.

The MPA Working Group performs biospheric model validation exercises that consider all relevant pathways from sources to humans leading to internal and external radiological exposure. The exercises are based on data available following the Chernobyl accident. These exercises are carried out as "blind tests" in which the modelers receive a scenario description and make predictions based on the information provided in the description. After all the modelers have submitted their predictions, they are provided with the measured data corresponding to the quantities that they predicted. The modelers are then expected to refine and/or recalibrate their models to yield predictions that are closer to the measurements.

A total of 11 models from 11 countries participated in the Scenario S exercise. The RESRAD model, as an equilibrium model, is the only "nondynamic" model that participated in this exercise. The other 10 models are all "dynamic" models; that is, they are designed to model seasonal and daily changes in the environment.

Most of the models were specifically written to analyze Scenario S cesium-137 contamination. For RESRAD, on the other hand, cesium-137 is just one of 84 radionuclides included in the code. Also, most of the other codes do not have a user interface and are "spreadsheet" programs. RESRAD has a user interface, which makes it the most advanced and user-friendly of all the models.

This document reports on the use of the RESRAD computer code in the S Scenario exercise.

\section{SCENARIO S DESCRIPTION}

This study involved the prediction of the radiological consequences of cesium-137 from Chernobyl-derived fallout in southern Finland and the comparison of predictions with measured values when available. The extent of the test region was 177,000 square kilometers, $86 \%$ of which was land and $14 \%$ of which was surface water. The set of data and conditions used in this test was termed "Scenario S." The details of the scenario are given in documents issued by the IAEA (1992b, 1996); some of this information is summarized in Appendix A.

The required endpoints of the validation exercise were the total deposition of cesium-137 in the test area; the concentrations in several food products (leafy vegetables, cereals, milk, beef, pork, game meat, wild mushrooms, wild berries, and freshwater fish); the concentrations in several animal feeds (pasture vegetation, barley, and oats); daily human intake for man, woman, and child; 
whole body content of man, woman, and child; the effective dose equivalent due to external radiation; the committed effective dose equivalent due to inhalation and ingestion; and the statistical distribution of the adult whole body content. The estimates of these quantities (except for total deposition) were required for different time periods. The $95 \%$ confidence interval for all the estimates was also requested.

\section{RESRAD}

\subsection{DESCRIPTION OF RESRAD}

RESRAD is a computer code developed at Argonne National Laboratory for the U.S. Department of Energy (DOE) to calculate site-specific residual radioactive materials guidelines and radiological dose/risk to an on-site individual at a radioactively contaminated site ( $\mathrm{Yu}$ et al. 1993). The code is continuously improved and updated in response to suggestions from users and to incorporate new features that facilitate user interaction and increase the capabilities and flexibility of the code. A recent improvement to RESRAD is the addition of a Latin hypercube-Monte Carlo preprocessor that allows statistical distributions to be specified in place of single values for input parameters. The code is being extended to include off-site modeling capability.

RESRAD uses a pathway analysis method in which a pathway sum is calculated to relate the radiological dose/risk to the concentration of the radionuclide in soil. The pathway sum is the sum of pathway factors for each of the applicable pathways. The pathway factor accounts for radioactive decay and ingrowth, transport, transfer, bioaccumulation, and radiological potency of the contaminant. RESRAD considers the following pathways:

- External radiation from ground;

- Inhalation of contaminated dust, radon and radon progeny, and gaseous airborne radionuclides;

- Ingestion of plant food contaminated by root uptake, foliar deposition, and irrigation water;

- Ingestion of meat and milk contaminated by fodder, livestock water, and soil ingestion;

- Ingestion of fish and aquatic foods contaminated by lake water; 
- Ingestion of water from a contaminated well or surface water source; and

- Ingestion of contaminated soil.

\subsection{MODIFICATIONS TO RESRAD}

RESRAD computes the concentrations of the nuclides in the surface water body by considering the transport of the nuclides through the unsaturated and saturated zones. However, in Scenario $S$ the surface water was contaminated by direct fallout on the surface of the water course and by contaminated runoff. Given the large extent of the study area and the large subsurface transport distances, groundwater-derived contamination of the surface water sources would not be significant over the time span of the study (50 years). Hence the code (RESRAD version 4.7) was modified by removing the groundwater transport pathway and by including the measured surface water concentrations for the first four years as input. The surface water concentration was assumed to decline solely because of radioactive decay beyond the fourth year after deposition. The code was also modified to compute and output the concentrations of the contaminants in different media.

\section{SIMULATING SCENARIO S ON RESRAD}

\subsection{ESTIMATION OF ENDPOINTS}

Because the version of RESRAD used in this study limited the numbers of vegetables, animal feeds, and meats to two, one, and one, respectively, all the required endpoints could not be obtained from a single series of simulations. In all, a total of 10 series of simulations were required - one each for the cesium-137 content of leafy vegetables, the cereals wheat and rye, wild berries, oats, barley, and pasture, one to estimate the nuclide content in fish and in pork, and one each to determine the intake and dose for man, woman, and child. The three runs for oats, barley, and pasture were used to determine the cesium-137 content in beef and milk.

\subsection{ESTIMATION OF CONFIDENCE INTERVAL}

The probabilistic RESRAD code was still under development when these simulations were performed. Hence the deterministic code was run repeatedly to generate a distribution of predictions in order to obtain the $95 \%$ confidence interval. Because 10 series of runs were required to obtain all the endpoints, the number of runs within each series was limited to 25. A Latin hypercube sampling (LHS) scheme was used to obtain 25 representative values of each of the inputs that were selected for the statistical study. The LHS routine has now been incorporated into RESRAD version 5.2. 


\subsection{INPUTS SELECTED FOR STATISTICAL STUDY}

Because the simulations for the statistical analysis had to be run manually, only those parameters that were highly uncertain were varied in each series. The soil-to-plant transfer factors for barley, oats, rye, wheat, peas and beans, potatoes, spinach, fruit, root vegetables, and fodder; the water-to-flesh bioaccumulation factor for fish; and the intake-to-edible-portion transfer factors for beef, pork, milk, poultry, and eggs were selected for the statistical study, because the value applicable to the region of study was not known a priori. The distribution of these factors and the values characterizing the distributions were obtained from the IAEA 9th Draft Working Document, Handbook of Parameter Values for the Prediction of Radionuclide Transfer in Temperate Environments (IAEA 1992a). The input concentrations of cesium-137 in soil and in the surface water body for the first four years after the passage of the radioactive Chernobyl plume were also allowed to vary in the statistical runs. The distributions of the concentrations were assumed to be normal. The standard deviation of the soil concentration was stated to be $10 \%$ of the mean in the scenario description. The mean and standard deviation of the surface water concentrations were obtained from the values given for the 12 drainage (fish) regions in the study.

\subsection{RESRAD INPUTS}

The information given in the scenario description had to be manipulated to yield the inputs required by RESRAD. The data preparation is discussed below.

\subsubsection{Thickness of Contaminated Zone}

The vertical distribution of cesium-137 in uncultivated soils was given in the scenario description and is summarized in Table A.1. Analysis of that data resulted in a distribution of depths within which $95 \%$ of the radiocesium was present. This distribution (Table 1) could have been sampled and included in the statistical analysis. However, the depth of contamination only affects the external radiation dose in this scenario because of the values chosen for mixing depth and root depth, and the methodology used to compute the radionuclide content in the contaminated zone. Hence, a single value of $10 \mathrm{~cm}$ was selected for the depth of contaminated zone.

TABLE 1 Distribution of Depth within Which $95 \%$ of the Cesium-137 in the Surface Soil Is Contained

\begin{tabular}{llllllllllllllll} 
Depth (cm) & 1 & 2 & 3 & 4 & 5 & 6 & 7 & 8 & 9 & 10 & 11 & 12 & 13 & 14 & 15 \\
$\begin{array}{l}\text { Number of sites in which } \\
\begin{array}{l}95 \% \text { of the Cs-137 is } \\
\text { within this depth }\end{array}\end{array}$ & 0 & 1 & 5 & 16 & 8 & 4 & 4 & 10 & 2 & 3 & 3 & 0 & 0 & 2 & 1 \\
\hline
\end{tabular}




\subsubsection{Cesium-137 Content of Contaminated Zone}

The areal deposition of cesium-137 in different parts of the test region given in the scenario description is summarized in Table A.2. This information yielded an average areal deposition rate of $20 \mathrm{kBq} \mathrm{m}^{-2}$ over the land and water surfaces. Together with the value of contaminated zone thickness chosen above and an assumed density of $1.6 \mathrm{~g} \mathrm{(cm})^{-3}$, this translated to a cesium-137 content of $3.4 \mathrm{pCi} \mathrm{g}^{-1}$. The scenario description stated that the error in the areal deposition rates of the different parts of the test region was characterized by a standard deviation equal to $10 \%$ of the mean. The cesium-137 in soil ( $\mathrm{pCi} \mathrm{g}^{-1}$ ) was assumed to be normally distributed with a mean of 3.4 and a standard deviation of 0.34 for the statistical study.

\subsubsection{Evapotranspiration Coefficient}

The scenario description states that "a typical value for evaporation for a lake in the south is $500 \mathrm{~mm} \mathrm{a}^{-1}\left[\mathrm{yr}^{-1}\right]$ and in the north $350-450 \mathrm{~mm} \mathrm{a}^{-1}$. Runoff from drainage areas FISH3, FISH4, and FISH5 to the watercourses typically is about $5-7 \mathrm{~L} \mathrm{~s}^{-1} \mathrm{~km}^{-2}$. About two-thirds of the precipitation evaporates." Hence an evapotranspiration coefficient of 0.667 was selected.

\subsubsection{Precipitation Rate}

The annual precipitation varies between 450 and $750 \mathrm{~mm}$; an average value of $0.6 \mathrm{~m} \mathrm{yr}^{-1}$ was used in the simulations.

\subsubsection{Irrigation Rate}

An irrigation rate of $0.08 \mathrm{~m} \mathrm{yr}^{-1}$ was used because the rainfall deficiency in the subregions ranged from 60 to $80 \mathrm{~mm}$ and 80 to $100 \mathrm{~mm}$.

\subsubsection{Runoff Coefficient}

The average runoff rate of $6 \mathrm{~L} \mathrm{~s}^{-1} \mathrm{~km}^{-2}$ and the mean precipitation of $0.6 \mathrm{~m} \mathrm{yr}^{-1}$ were combined to obtain a runoff coefficient of 0.32 . 


\subsubsection{Soil Water Distribution Coefficient of Cesium-137}

The RESRAD default value of $1,000 \mathrm{~cm}^{3} \mathrm{~g}^{-1}$ was used. Under the conditions chosen to represent this scenario, a nonreactive solute will travel down approximately one meter per year. A distribution coefficient of $100 \mathrm{~cm}^{3} \mathrm{~g}^{-1}$ would have slowed the downward movement of cesium-137

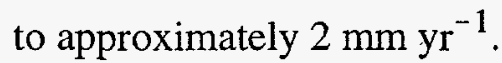

\subsubsection{Dust Mass Loading}

The cesium-137 in air, one meter above ground level, given in the scenario description is shown in Figure 1. The concentration of cesium-137 dropped steadily for 15 days following the passage of the first plume, and then steadied at a value of $0.0013 \mathrm{~Bq} \mathrm{~m}^{-3}$. These air concentrations were from two monitoring stations in population region number 8 . The areal deposition rate in this population region was $13,600 \mathrm{~Bq} \mathrm{~m}^{-2}$. Combining these values with an assumed soil bulk density of $1.6 \mathrm{~g} \mathrm{~cm}^{-3}$ and the depth of contamination of $0.1 \mathrm{~m}$ gave a mass loading of $0.0156 \mathrm{~g} \mathrm{~m}^{-3}$. The dilution due to soil mixing (mixing depth $0.2 \mathrm{~m}$ ) was not considered because it was not likely to have occurred within 15 days of plume passage.

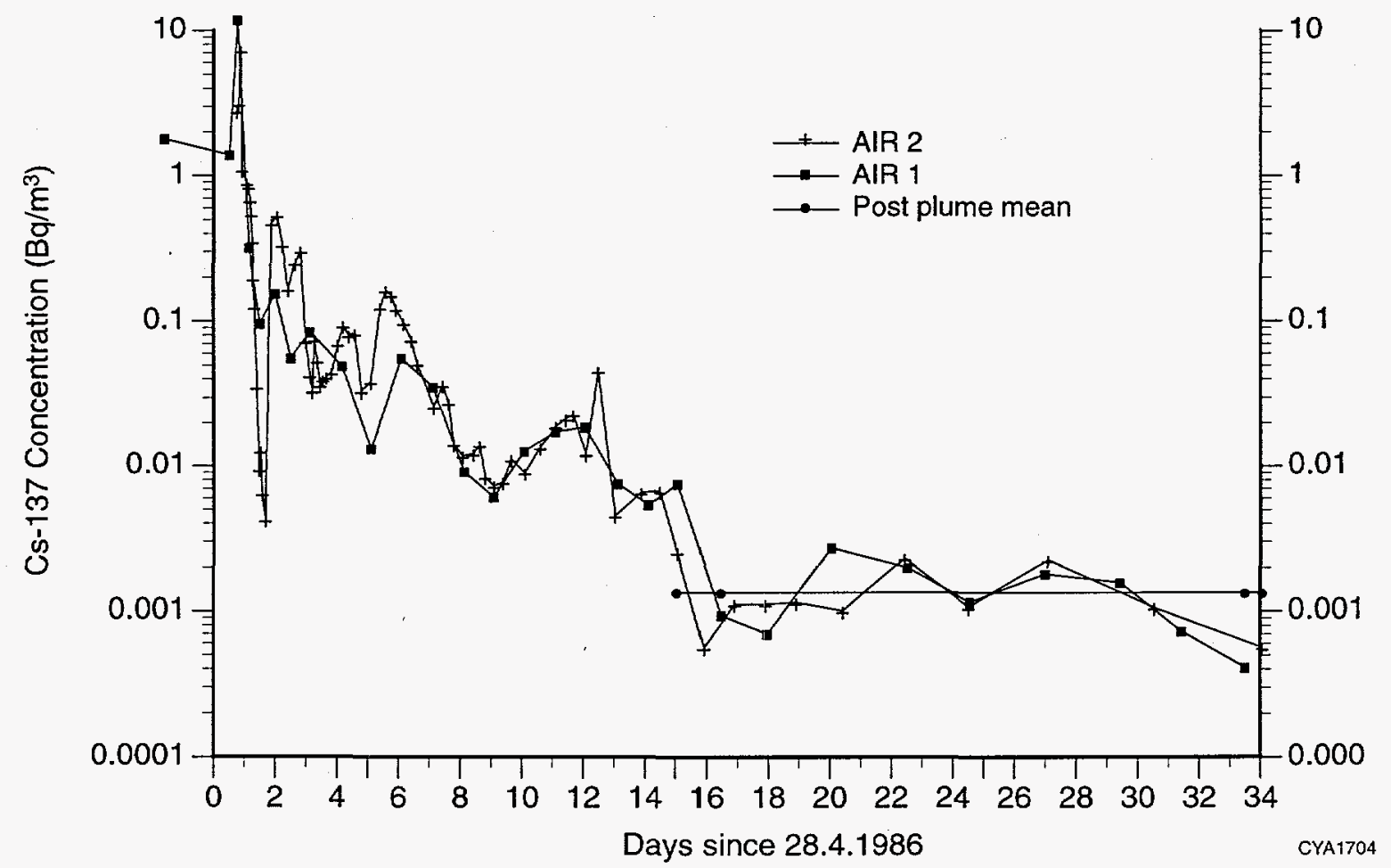

FIGURE 1 Cesium-137 Concentration in Air One Meter above Ground Level 


\subsubsection{Depth of Soil Mixing}

The depth of soil mixing was set to the value of the common plow depth of $20 \mathrm{~cm}$.

\subsubsection{Depth of Roots}

The depth of roots was set to $20 \mathrm{~cm}$.

\subsubsection{Occupancy Factor}

The amount of time per day spent outdoors by an average individual for all activities other than commuting to and from work was 28 minutes. Assuming the average work commute to be 30 minutes each way per work day, the fraction of time outdoors was 0.05 $([28+2 \times 30 \times 5 / 7] / 1440)$, and the fraction of time indoors was 0.95 .

\subsubsection{Inhalation Rate}

An inhalation rate of $7,300 \mathrm{~m}^{3} \mathrm{yr}^{-1}$ was used.

\subsubsection{Erosion Rate}

Because of the vast extent of the contaminated region, erosion will only redistribute the cesium-137 within the contaminated area and will not significantly affect the results. Hence the erosion rate was set to zero.

\subsubsection{Cesium-137 Content of Surface Water}

The values for radiocesium content of each surface water body at different times of the year (Table A.3) were averaged to obtain a mean annual content. The mean annual content of different surface water bodies for each year was analyzed to obtain the mean and standard deviation of cesium-137 content for each year. Because the volumes of the surface water bodies were not known, they were weighted equally. The distribution of the surface water cesium- 137 content was assumed to be normal for the statistical study. Table 2 gives the mean and standard deviation of the cesium-137 in the surface water courses for each of the four years. 


\subsubsection{Fraction of Groundwater Usage}

The scenario description states that $40 \%$ of the population uses surface water for household use, and the rest of the population uses groundwater. The same proportion of water source was assumed for irrigation water and for livestock water.

\subsubsection{Human Food Consumption Rates}

The consumption rates of adults and children for various foods are given in Table A.4. The consumption rates were combined to obtain the consumption rates for the six food classes required by RESRAD (Table 3). The proportions of food items in each food class are given in the footnotes to Table 3 . These proportions were used to compute the composite soil-to-food and composite intake-to-meat transfer factors for the intake and dose runs.

TABLE 3 Human Food Consumption Rates

\begin{tabular}{|c|c|c|c|}
\hline \multirow[b]{2}{*}{ RESRAD Food Category } & \multicolumn{3}{|c|}{ Consumption $\left(\mathrm{kg} \mathrm{yr}^{-1}\right)$} \\
\hline & Man & Woman & Child \\
\hline Nonleafy vegetables ${ }^{\mathrm{a}}$ & 300 & 280 & 211 \\
\hline Leafy vegetables & 12.8 & 16.4 & 18.0 \\
\hline Milk & 330 & 220 & 274 \\
\hline Meat and poultry ${ }^{\mathrm{b}}$ & 75 & 54 & 71 \\
\hline Fish & 5.5 & 3.7 & 5.0 \\
\hline Other aquatic food & 0 & 0 & 0 \\
\hline
\end{tabular}

a $44 \%$ fruit, $23 \%$ potato, $6 \%$ roots, $1 \%$ peas/beans, $15 \%$ wheat, $6 \%$ rye, $2 \%$ barley, $2 \%$ oats.

b $33 \%$ beef, $41 \%$ pork, $9 \%$ poultry, $17 \%$ eggs.
TABLE 2 Cesium-137 in Surface Water Bodies

\begin{tabular}{ccc} 
Year & Mean & $\begin{array}{c}\text { Standard } \\
\text { Deviation }\end{array}$ \\
\hline 1986 & 23.1 & 3.9 \\
1987 & 5.02 & 1.01 \\
1988 & 2.89 & 0.58 \\
1989 & 2.02 & 0.37 \\
\hline
\end{tabular}




\subsubsection{Livestock Consumption Rates}

The consumption rates of beef cattle and dairy cows are given in Tables A.5 and A.6. The silage, hay, and pasture feeds were categorized as fodder, and the rest of the feeds were apportioned between barley and oats in the ratio of their production in the study area. Although the feeding rates varied within the study region, the consumption rates were not subjected to a statistical analysis. Because the feeding rates of swine and poultry and the water intake rates of beef cattle and dairy cows were not stipulated in the scenario description, the values in Scenario CB, the first scenario issued by the VAMP-MPA working group, were used. Table 4 gives the consumption rates that were used in the runs to determine the cesium-137 contents of beef, milk, and pork.

Because the version of RESRAD used in this study allowed only one meat and one milk pathway, and because the meat livestock and the dairy livestock are fed the same single feed (a generic fodder), a two-step weighted-averaging procedure was required to arrive at the livestock feed rates and the livestock-intake-to-edible-product transfer factors. The procedure is described in Appendix B.

\subsubsection{Soil-to-Plant Root Uptake Factors}

The mean and the geometric standard deviation of the root-to-edible-plant transfer factor (dry weight basis) used in this study are given in Table 5, together with the typical values of dry weight/wet weight from IAEA (1992a). The 95\% uncertainty factors given in the IAEA (1992a) document were adjusted for areal and temporal averaging by a factor of 3 following the guidance

TABLE 4 Livestock Feed Consumption Rates

\begin{tabular}{lcccc}
\hline & \multicolumn{5}{c}{ Consumption $\left(\mathrm{kg} \mathrm{yr}^{-1}\right)$} \\
\cline { 2 - 5 } \multicolumn{1}{c}{ Feed } & $\begin{array}{c}\text { Dairy } \\
\text { Cows }\end{array}$ & $\begin{array}{c}\text { Beef } \\
\text { Cattle }\end{array}$ & Pork & Poultry \\
\hline Fodder & 36.3 & 11.7 & 0 & 0 \\
Barley & 3.82 & 2.14 & 2 & 0.03 \\
Oats & 2.76 & 1.54 & 0 & 0.03 \\
Rye & 0 & 0 & 0 & 0.03 \\
Wheat & 0 & 0 & 0 & 0.03 \\
Water & 60 & 50 & 8 & 0.25 \\
\hline
\end{tabular}


TABLE 5 Soil-to-Plant Root Uptake Transfer Factors Used in This Study

\begin{tabular}{llcccc}
\hline \multicolumn{1}{c}{ Foodstuff } & Mean & $\begin{array}{c}\text { Geometric } \\
\text { Standard } \\
\text { Deviation }\end{array}$ & $\begin{array}{c}\text { Lower } \\
\text { Bound }\end{array}$ & $\begin{array}{c}\text { Upper } \\
\text { Bound }\end{array}$ & $\begin{array}{c}\text { Dry/Wet } \\
\text { Weight }\end{array}$ \\
\hline Fodder & 0.15 & 1.44 & 0.050 & 0.448 & 0.10 \\
Barley & 0.03 & 1.47 & 0.009 & 0.095 & 0.86 \\
Oats & 0.059 & 1.47 & 0.019 & 0.187 & 0.86 \\
Rye & 0.015 & 1.65 & 0.003 & 0.067 & 0.86 \\
Wheat & 0.018 & 1.47 & 0.006 & 0.057 & 0.86 \\
Pea, bean & 0.023 & 1.65 & 0.005 & 0.103 & 0.25 \\
Potato & 0.1 & 1.65 & 0.022 & 0.449 & 0.21 \\
Root vegetable & 0.28 & 1.57 & 0.072 & 1.084 & 0.13 \\
Fruit vegetable & 0.22 & 1.47 & 0.069 & 0.699 & 0.06 \\
Spinach & 0.24 & 1.47 & 0.076 & 0.762 & 0.08 \\
\hline
\end{tabular}

in that document; for a lognormal distribution, the geometric standard deviation is then the sixth root of the $95 \%$ uncertainty factor.

\subsubsection{Intake-to-Food Product (Livestock) Transfer Factors}

Table 6 gives the distribution statistics of the intake to the livestock-food-product transfer factors from IAEA (1992a). The transfer factor for veal (cattle less than one year old) was not used in the initial simulations (blind predictions) but is included for the purpose of discussion and for the post-observation predictions.

\subsubsection{Water-to-Fish Bioaccumulation Factor}

The distribution statistics for the fresh-water-to-fish transfer factor (i.e., bioaccumulation factor) for cesium-137 from IAEA (1992a) are as follows: minimum $=30$, likeliest $=2,000$, maximum $=3,400$. This factor correlates the equilibrium concentration in fish to the concentration in water. 
TABLE 6 Intake-to-Animal-Product Transfer

Factors Used in This Study

\begin{tabular}{llll}
\hline Foodstuff & Minimum & Likeliest & Maximum \\
\hline Eggs & 0.06 & 0.45 & 2.5 \\
Poultry & 0.3 & 12 & 12 \\
Pork & 0.03 & 0.24 & 1.1 \\
Milk & 0.001 & 0.0079 & 0.027 \\
Beef & 0.015 & 0.051 & 0.056 \\
Veal & 0.04 & 0.18 & 0.56 \\
\hline
\end{tabular}

5 RESULTS AND DISCUSSION

Figures 2 through 9 illustrate the RESRAD blind predictions. The figures also show the measured or STUK (Finnish Centre for Radiation and Nuclear Safety) estimated values of the same quantities. The post-observation revisions are shown in Figures 10 through 16 . The endpoints of the study fall into one of two groups. The first group, consisting of the cesium-137 concentrations in human food products, animal feed, and in the human body, are all measurable quantities. Observed means and $95 \%$ confidence intervals of these quantities are available on the basis of numbers of observations ranging from 10 to 440, except for the values for concentration in pasture, which are based on three to five observations for the years 1987 through 1990. Measured values are not available for annual intake of cesium-137 and radiation dose, which make up the second group; estimates of these quantities are available. The RESRAD predictions are compared with these measured or estimated values in the following sections.

\subsection{COMPARISON OF BLIND PREDICTIONS WITH MEASURED OR ESTIMATED VALUES}

The blind RESRAD predictions for the cesium-137 content in pasture, beef, milk, barley, oats, berries, wheat, rye, and fish deviate significantly from the measured values. These deviations are discussed in Sections 5.1.1 through 5.1.6. Predictions for dose, intake, and whole body counts are discussed in Sections 5.1.7 through 5.1.9. 

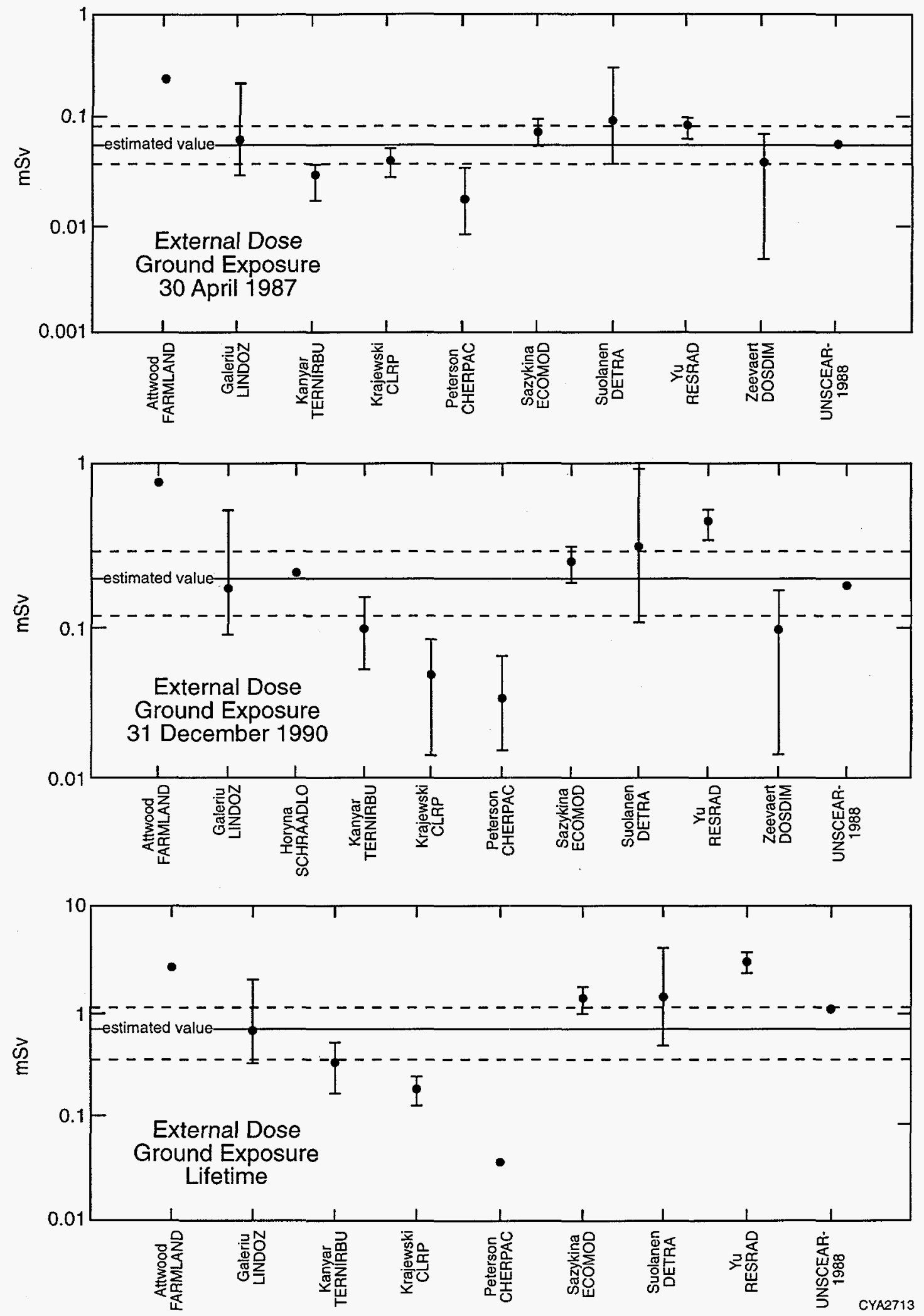

FIGURE 2 Comparison of Model Predictions of External Dose from Ground Exposure with STUK Estimates 

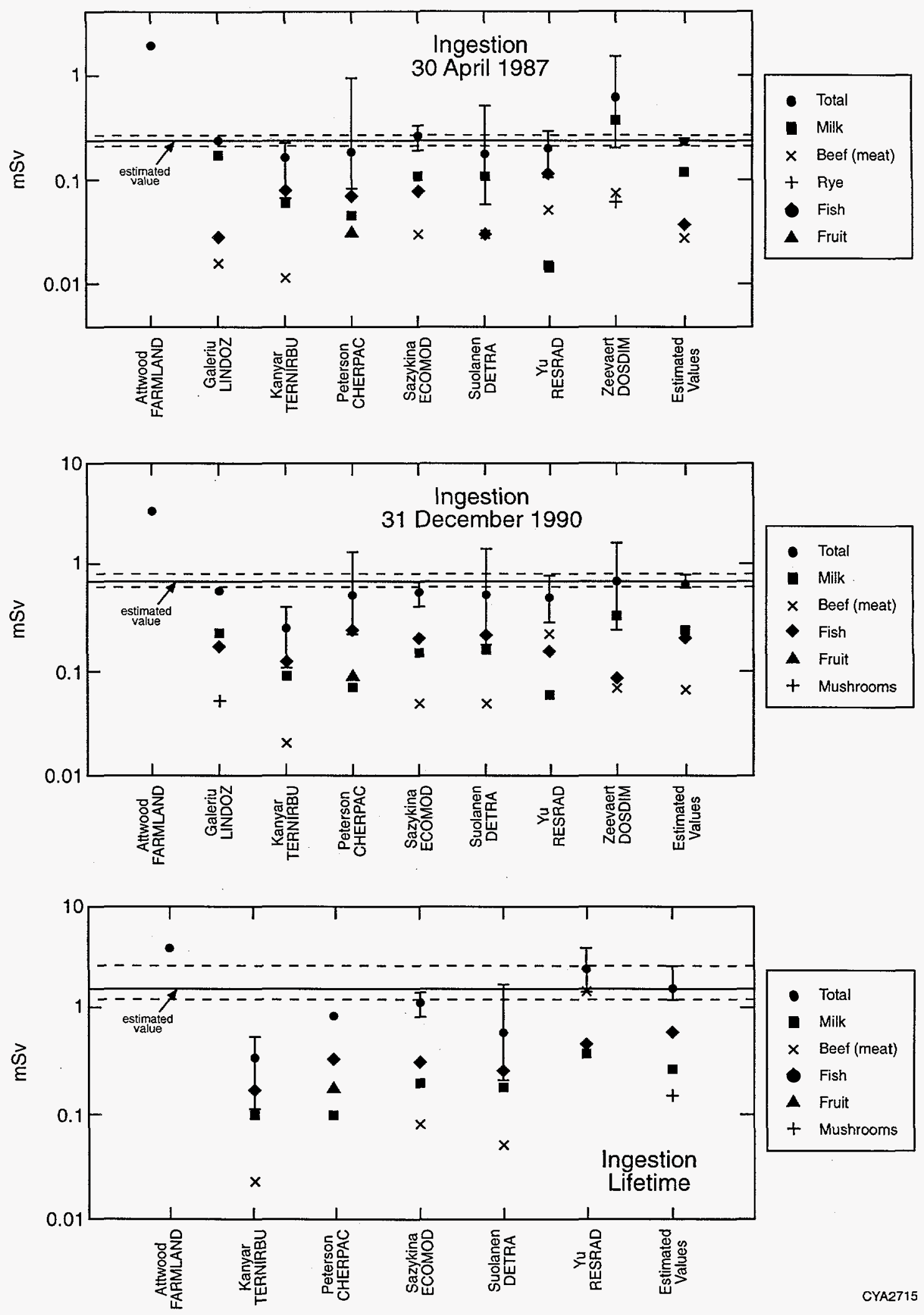

FIGURE 3 Comparison of Model Predictions of Radiological Dose from Ingestion with STUK Estimates 

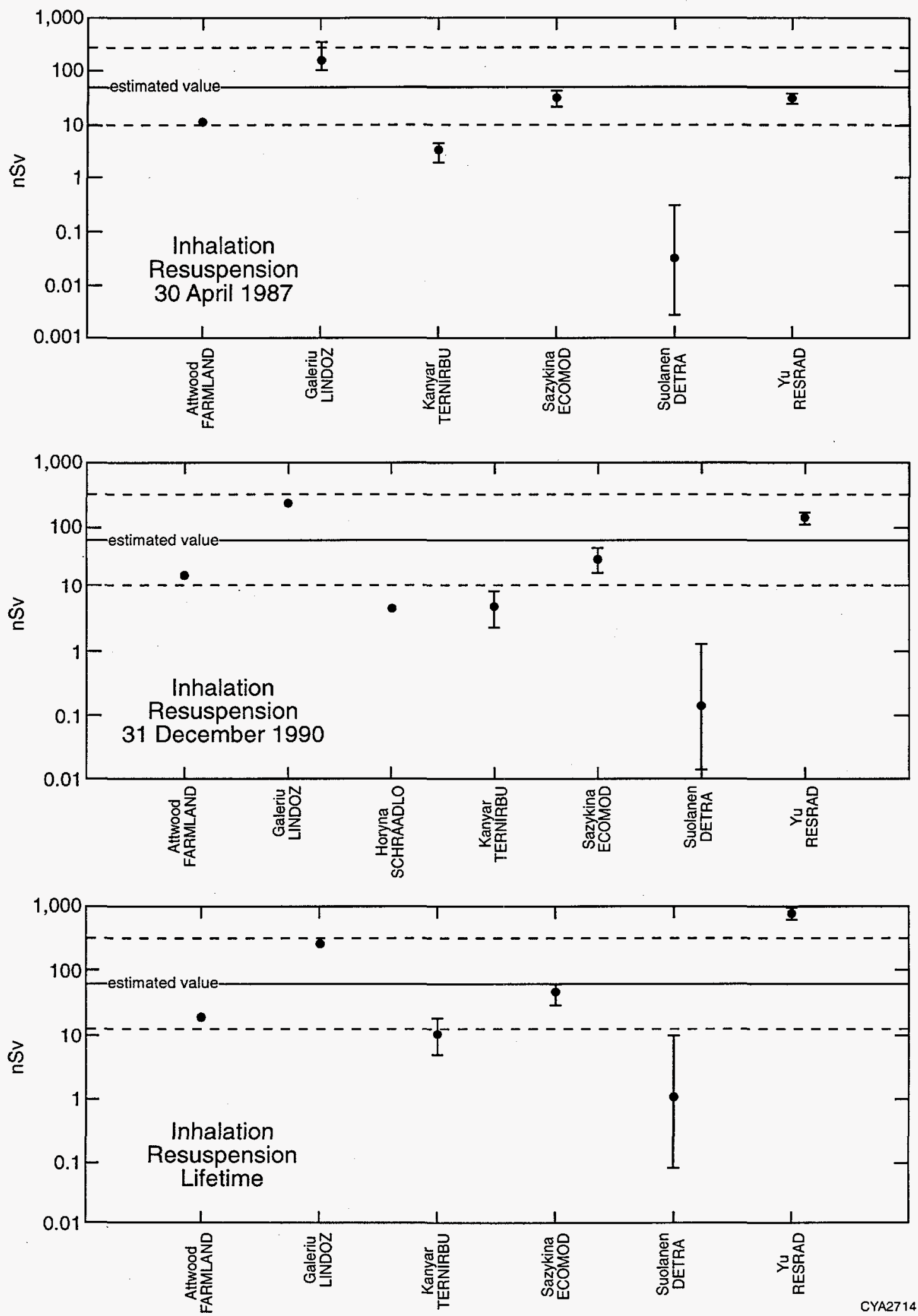

FIGURE 4 Comparison of Model Predictions of Radiological Dose from Inhalation from Resuspension with STUK Estimates 

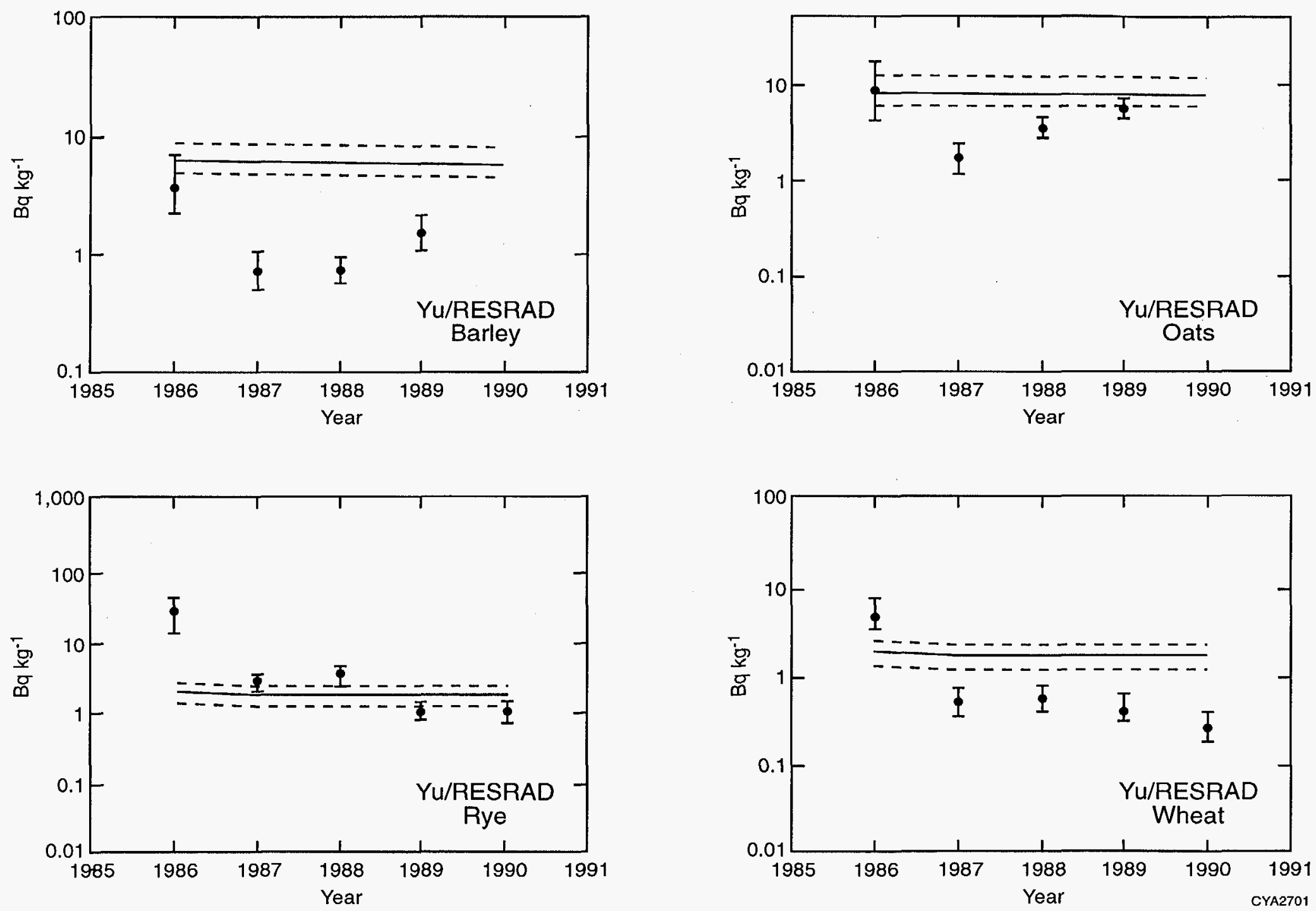

FIGURE 5 Comparison of RESRAD Predictions of Cesium-137 Content in Barley, Oats, Rye, and Wheat with Measured Values 

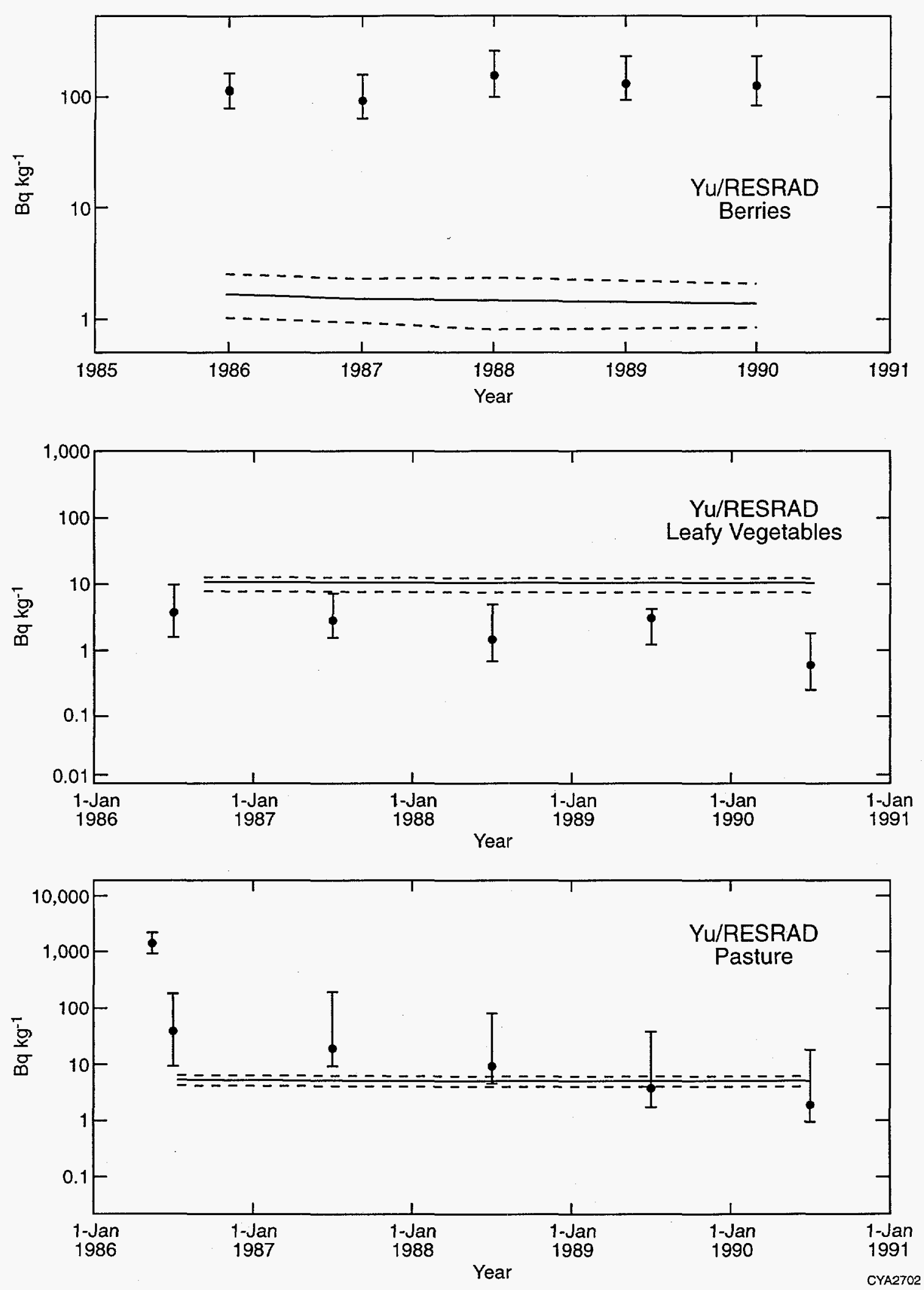

FIGURE 6 Comparison of RESRAD Predictions of Cesium-137 Content in Berries, Leafy Vegetables, and Pasture with Measured Values 

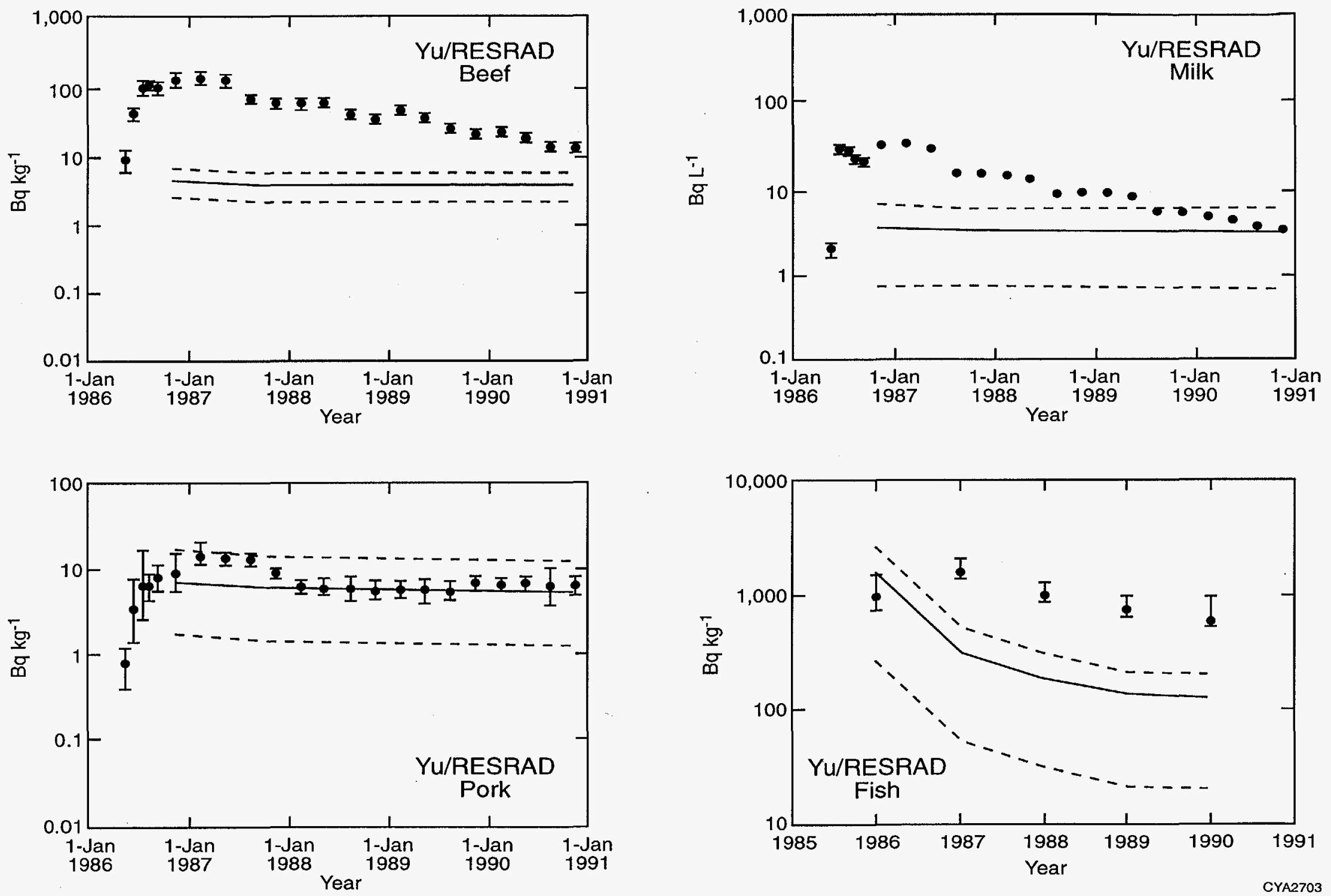

FIGURE 7 Comparison of RESRAD Predictions of Cesium-137 Content in Beef, Milk, Pork, and Fish with Measured Values 

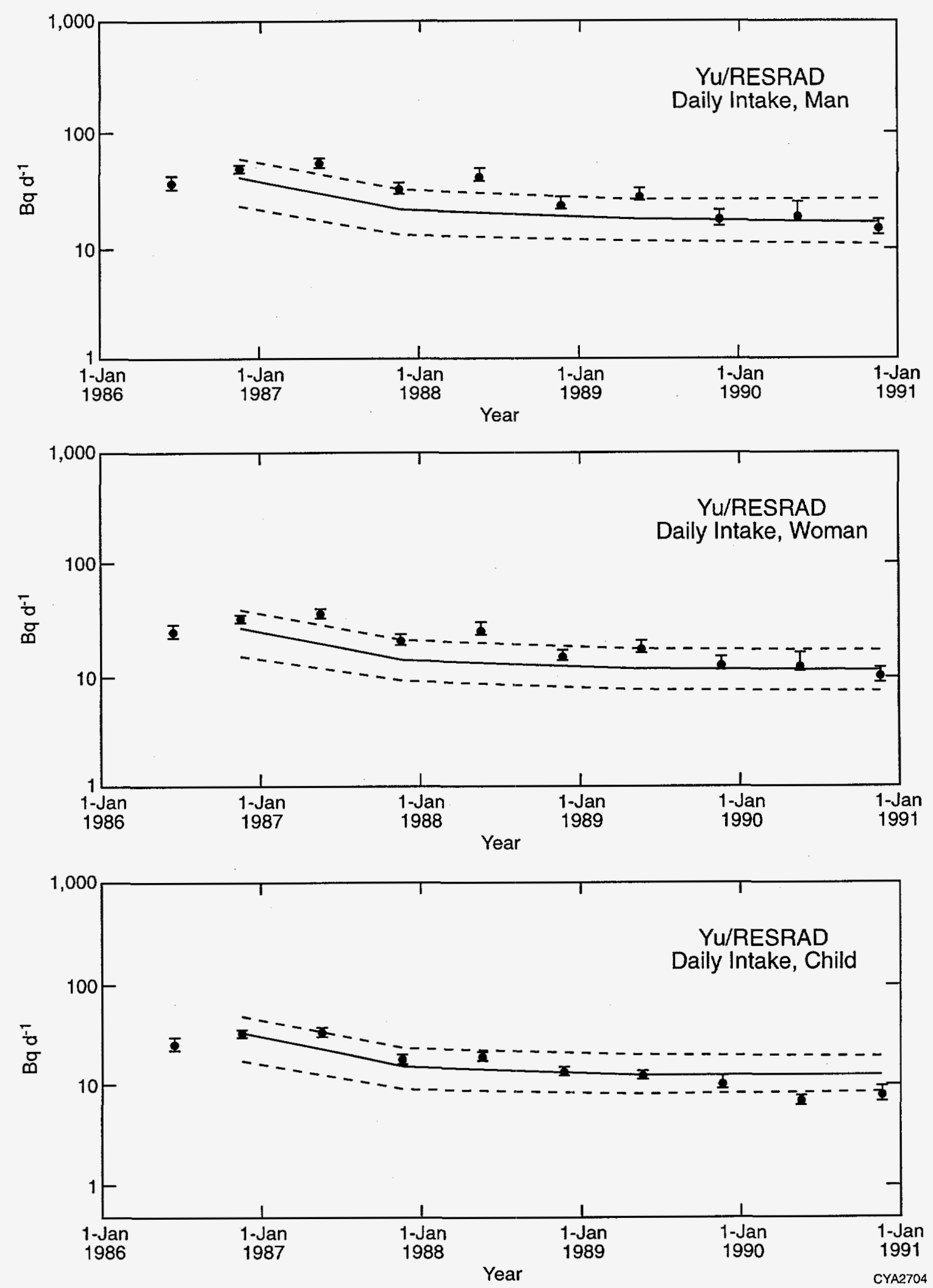

FIGURE 8 Comparison of RESRAD Predictions of Daily Intake of Cesium-137 by Man, Woman, and Child with STUK Estimates 

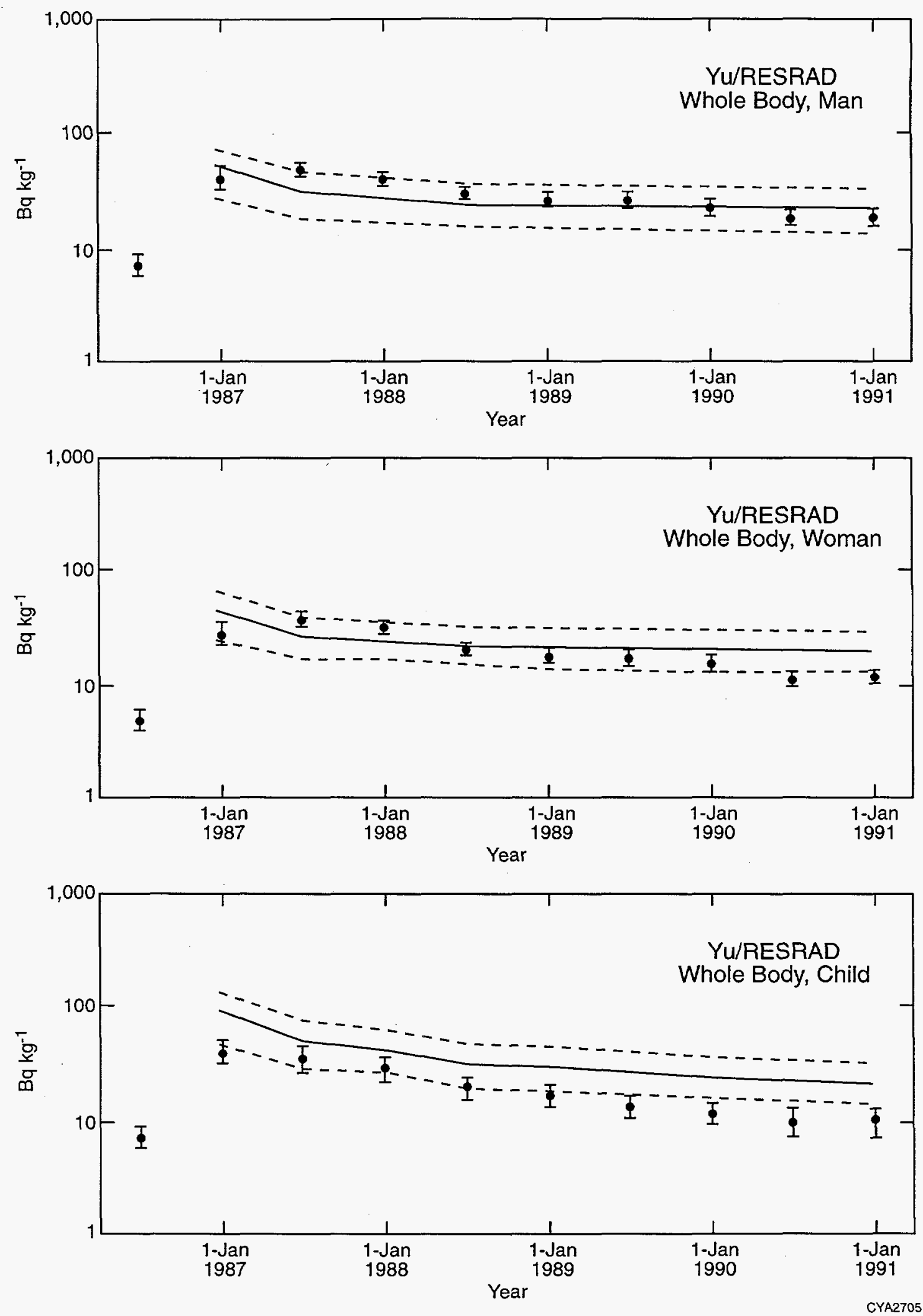

FIGURE 9 Comparison of RESRAD Predictions of Whole Body Cesium-137 Burden of Man, Woman, and Child with Measured Values 

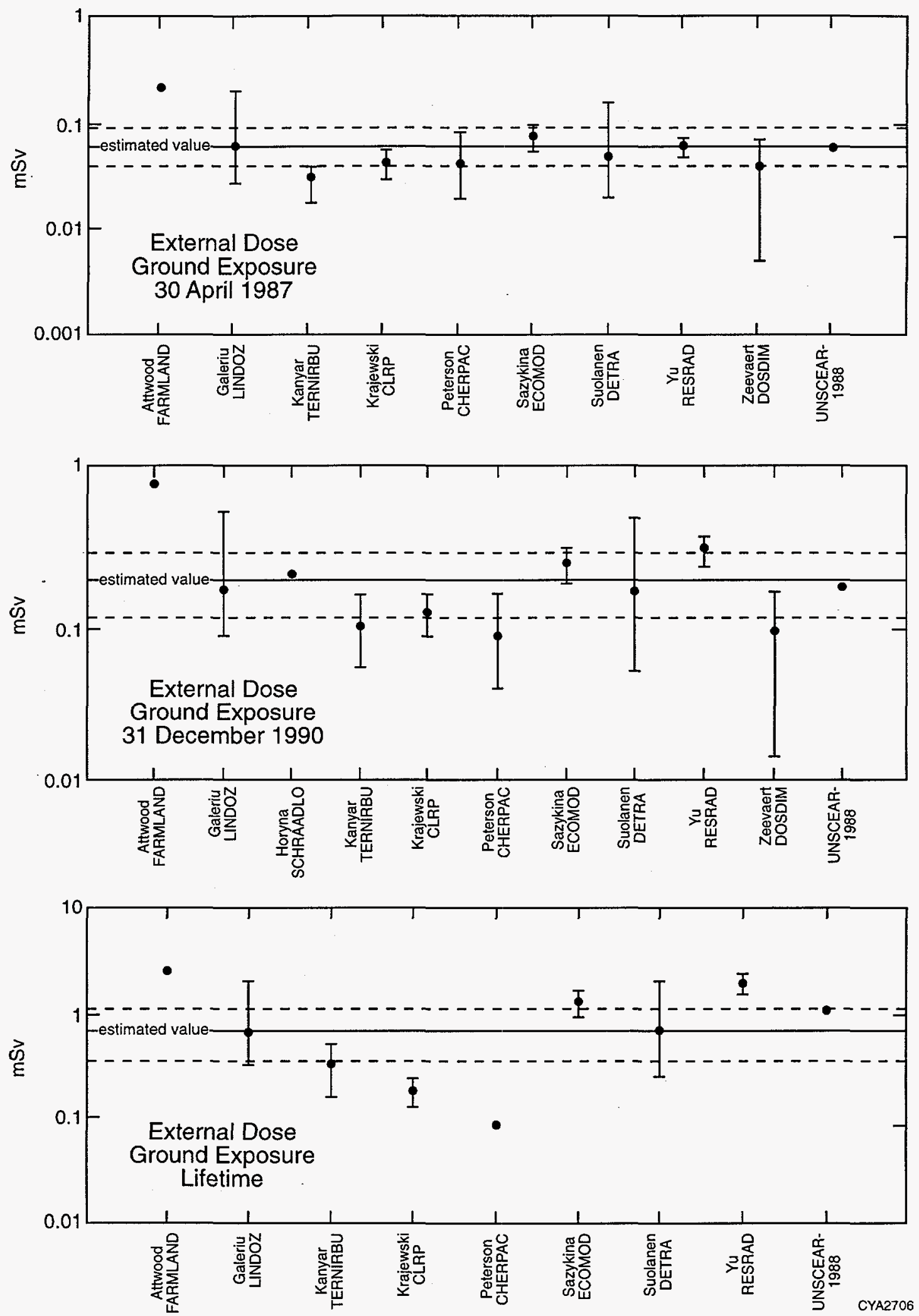

FIGURE 10 Comparison of Revised Model Predictions of External Dose from Ground Exposure with STUK Estimates 

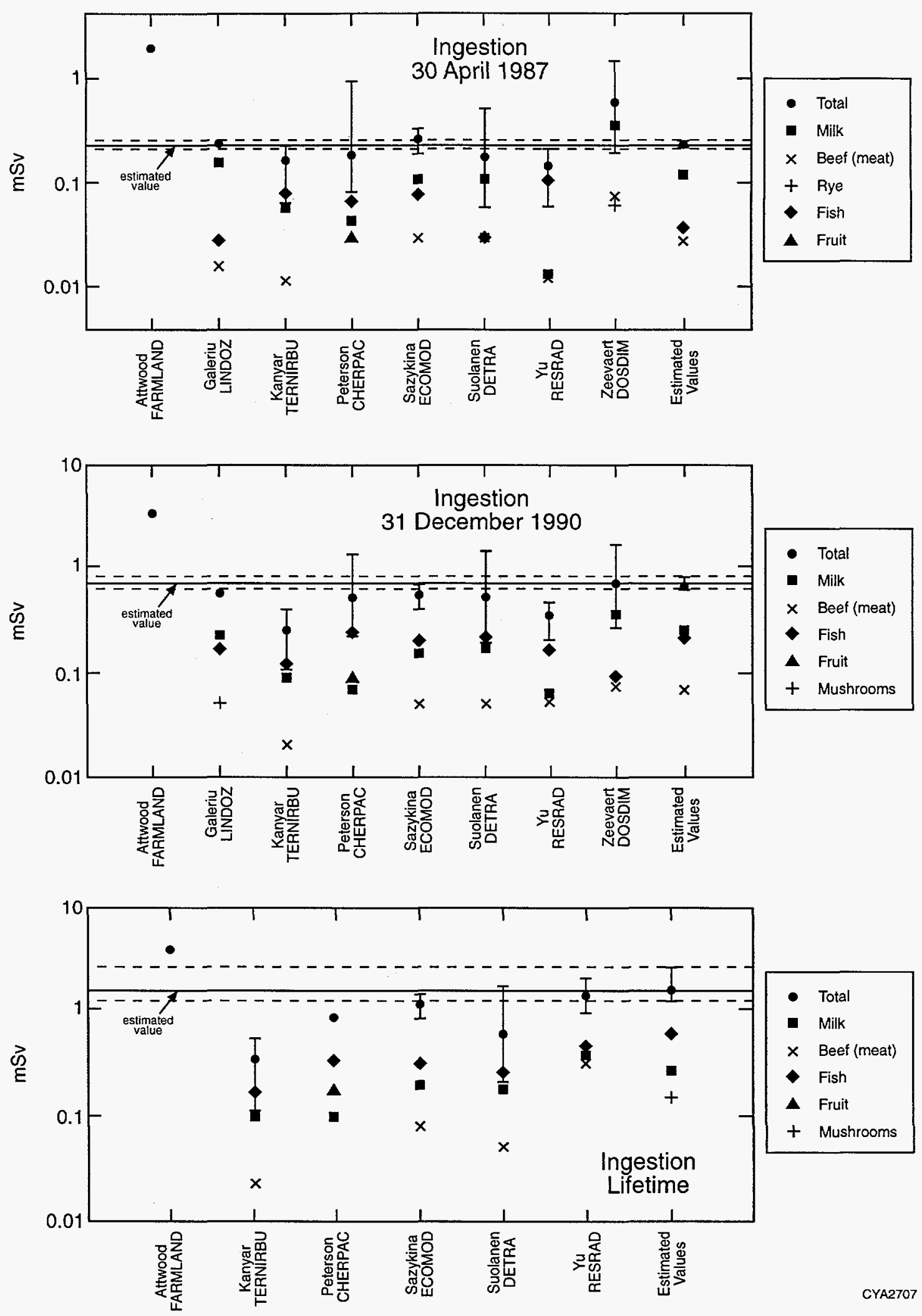

FIGURE 11 Comparison of Revised Model Predictions of Radiological Dose from Ingestion with STUK Estimates 

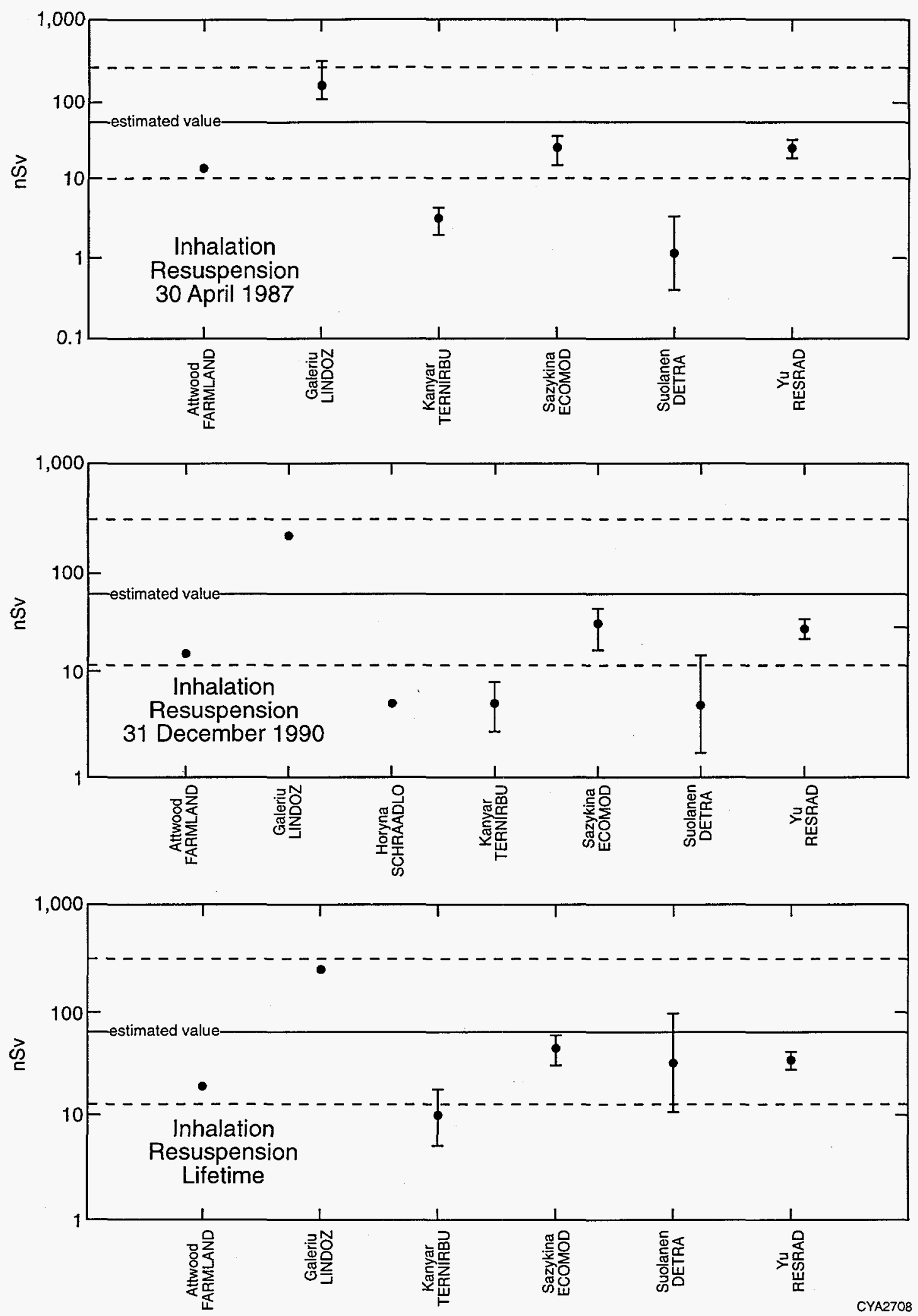

FIGURE 12 Comparison of Revised Model Predictions of Radiological Dose from Inhalation from Resuspension with STUK Estimates 

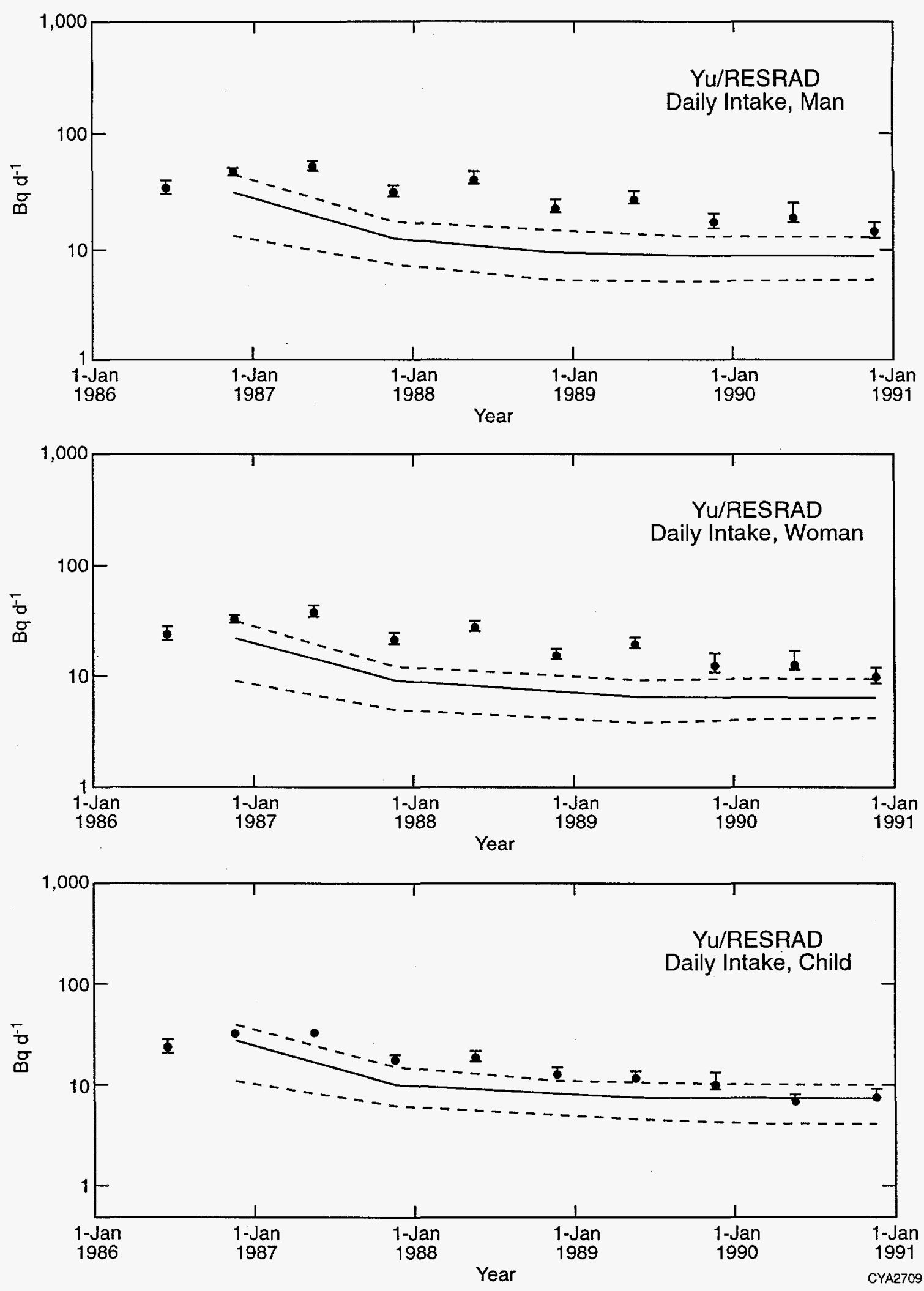

FIGURE 13 Comparison of Revised RESRAD Predictions of Daily Intake of Cesium-137 by Man, Woman, and Child with STUK Estimates 

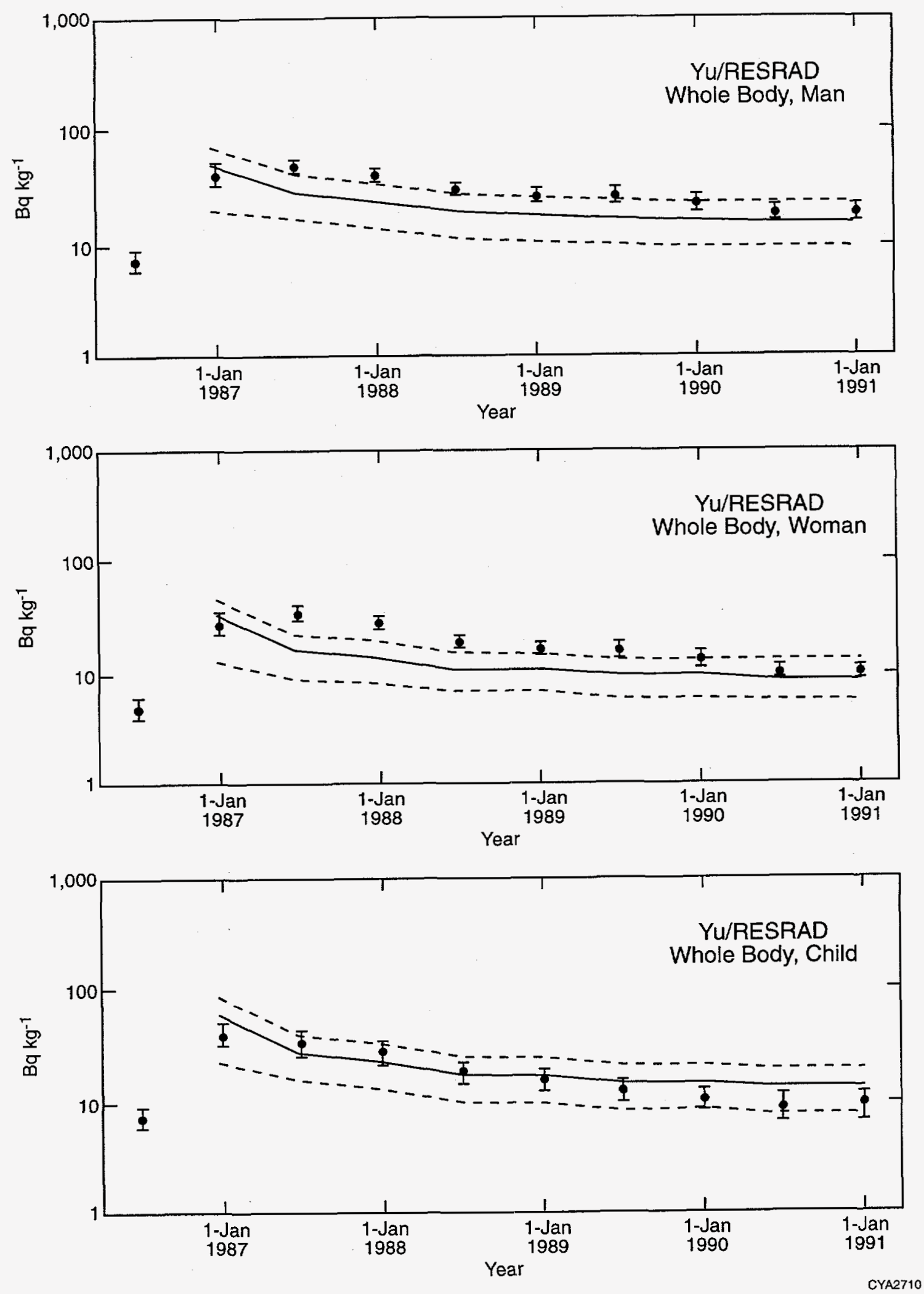

FIGURE 14 Comparison of Revised RESRAD Predictions of Whole Body Cesium-137 Burden of Man, Woman, and Child with Measured Values 


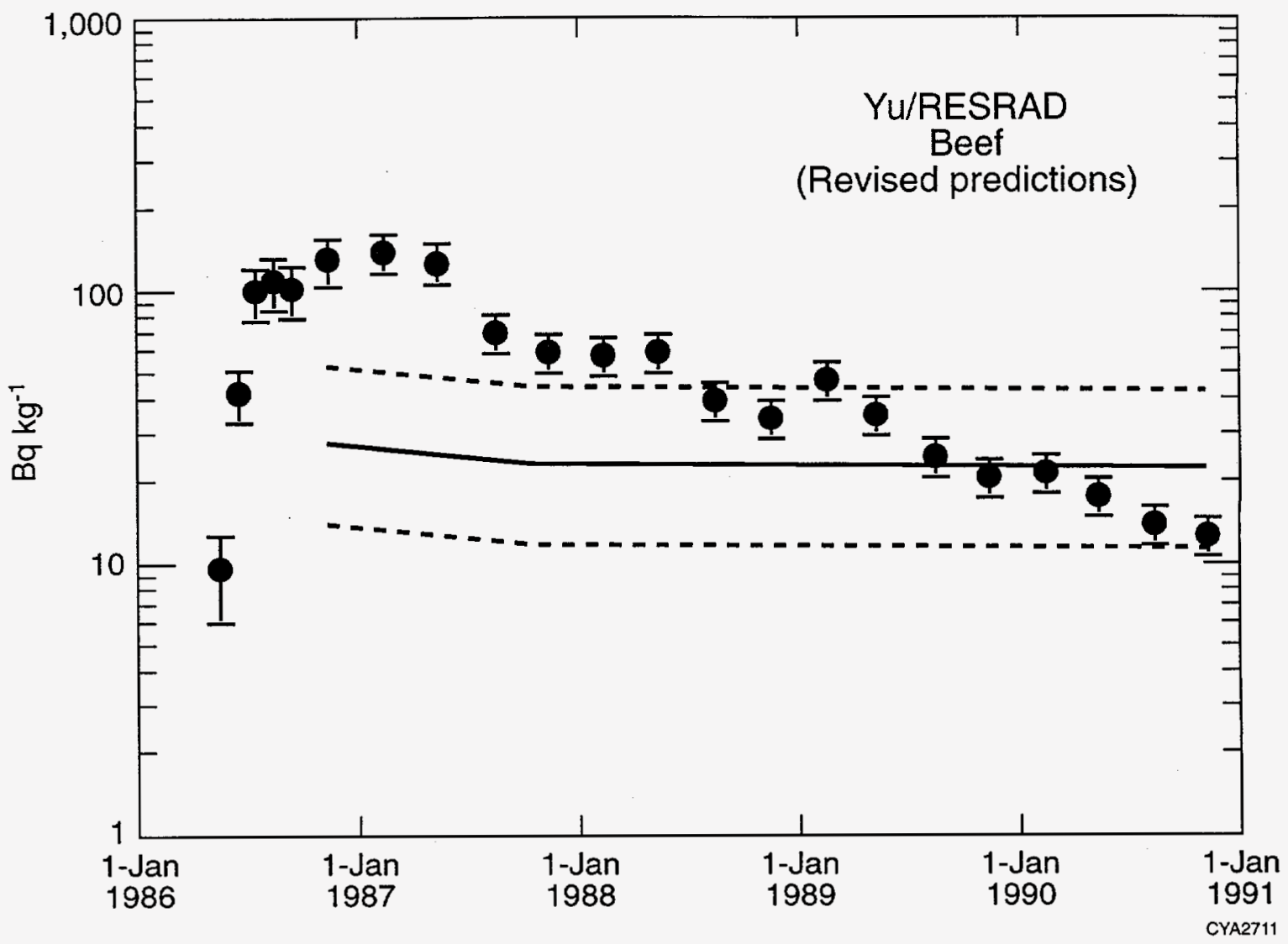

FIGURE 15 Comparison of Revised RESRAD Predictions of Cesium-137 Content in Beef with Measured Values

\subsubsection{Pasture}

The measured values of cesium-137 in pasture vegetation in May 1986 were on the order of $1 \mathrm{kBq} \mathrm{kg}{ }^{-1}$ because of direct deposition from the radioactive cloud resulting from the Chernobyl accident. This value decreased by a factor of 40 in July 1986, possibly due to dilution by new growth. Over the next four years, the concentration in pasture vegetation declined with a half life of 0.9 years. It should be noted that the May and July 1986 values were based on 99 and 33 measurements, respectively, while the values for the other years were based on three to five samples. The RESRAD prediction for July 1986 is lower by a factor of 7, and the concentration declines in subsequent years at the radioactive half-life. The July 1986 prediction is lower than the measured value because it does not include the high initial deposition from the radioactive cloud. The RESRAD predictions for the subsequent years are also lower because they do not account for any residual cesium-137 remaining in the pasture vegetation from the previous year. 

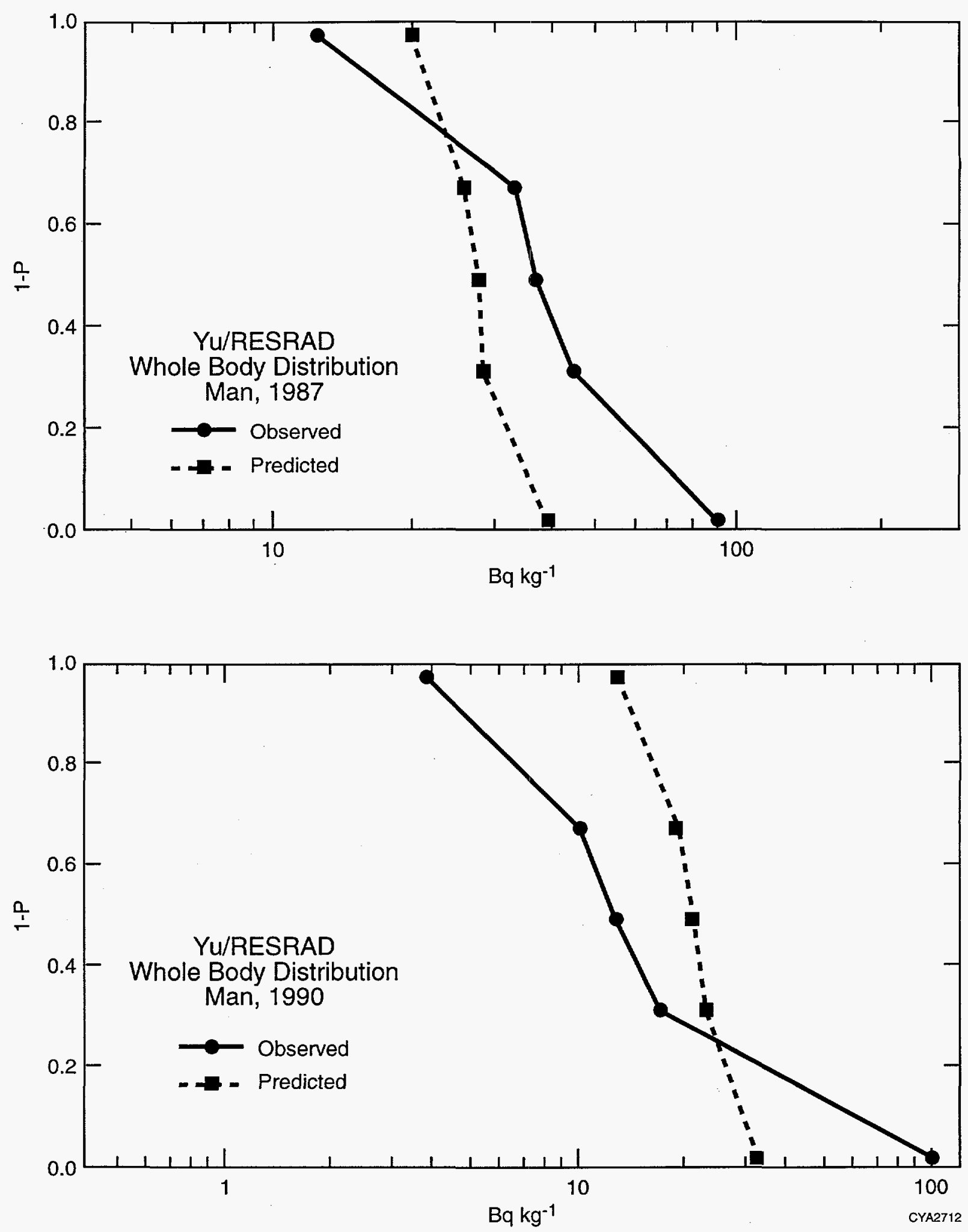

FIGURE 16 Comparison of Revised RESRAD Predictions of the Distribution of Whole Body Cesium-137 Burden of Man with Measured Values 


\subsubsection{Beef}

The measured concentration in beef rose rapidly to about $100 \mathrm{~Bq} \mathrm{~kg}^{-1}$ by July 1986 and remained in the hundreds until the second quarter of 1987; it then declined, with a half-life of 1.2 years, to a value of 10 at the end of 1990 . The RESRAD predictions declined from 4.5 to $3.5 \mathrm{~Bq} \mathrm{~kg}^{-1}$. One reason for the low predictions could be the choice of distribution for the intake-toanimal-product transfer factor; the transfer factor for "beef" was used instead of that of "veal" (cattle under one year of age). Another reason is the underprediction (by RESRAD) of the cesium-137 concentration in the feed. Figure 17 illustrates the effects of the choice of transfer factor and the underprediction of feed concentrations. If the beef transfer factor is applied to the specified cattle feed consumption rates and the measured feed (pasture, barley, oats) concentrations, the upper bound of the estimate is lower than the lower bound of the measured concentration in beef. If the veal transfer factors are used instead of beef transfer factors, the estimated range encompasses the observed range, although the spread of the estimates is much greater than the spread of the observed values. The third reason is that livestock feed was obtained from the northern part of the test region where sandy soil conditions prevail. Unlike clayey soils which can irreversibly bind cesium and make it unavailable for root uptake, sandy soils do not inhibit the uptake of cesium.

\subsubsection{Milk}

The measured concentration in milk soared to about $30 \mathrm{~Bq} \mathrm{~kg}^{-1}$ by June 1986 and remained in the 30s until the first quarter of 1987; it then declined, with a half-life of 1.3 years, to a value of 3 at the end of 1990. The RESRAD predictions declined from 3.3 to $2.7 \mathrm{~Bq} \mathrm{~kg}^{-1}$. One reason for the low predictions is the underprediction (by RESRAD) of the cesium-137 concentration in the feed. Figure 18 illustrates the effect of the underprediction of the feed concentrations. If the milk transfer factor is applied to the specified dairy cow feed consumption rates and the measured feed (pasture, barley, oats) concentrations, the estimated range encompasses the observed range, although the spread of the estimates is much greater than the spread of the observed values (Figure 18). Also, as stated in Section 5.1.2, use of feed from the northern part of the test region is another reason for the high cesium content observed in milk.

\subsubsection{Cereals}

The measured values of the concentration of cesium-137 in oats and barley show similar trends: a high value in the first year is followed by a drop in the second year and a rise over the next two years. Because of a misinterpretation of the required endpoints, the cesium-137 content in a mixed cereal ( $60 \%$ wheat, $24 \%$ oats, $8 \%$ barley, and $8 \%$ rye) was determined instead of the content in wheat and in rye. The observed cesium- 137 content in rye and wheat dropped sharply in the second year and then declined slowly over the next three years. 
Mean "Beef" Transfer Factor

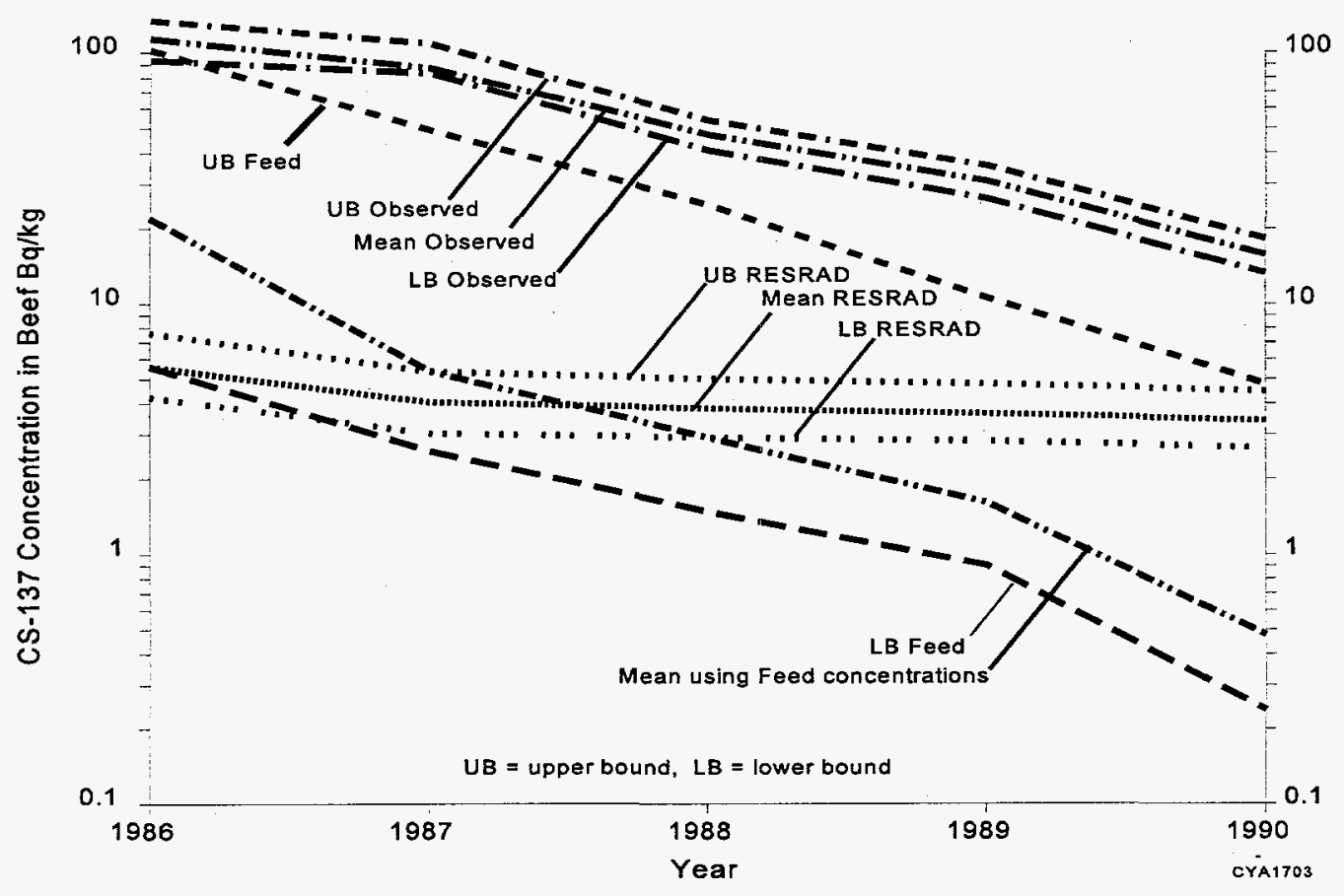

Mean "Veal" Transfer Factor

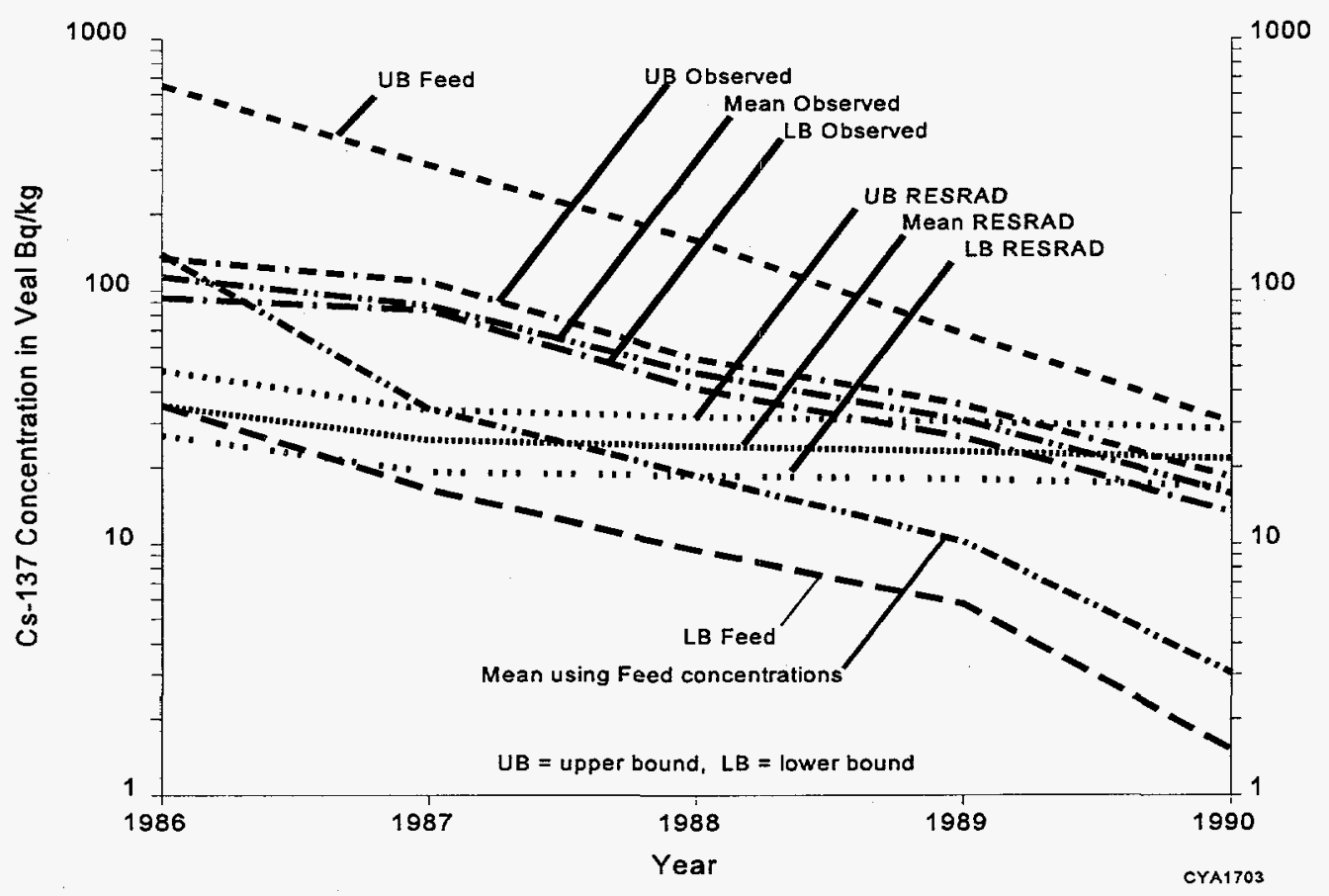

FIGURE 17 Comparison of Observed Cesium-137 Concentrations in Beef with Estimates Based on Beef and Veal Transfer Factors and on Measured and RESRAD Predicted Concentrations in Animal Feed 
Mean Milk Transfer Factor

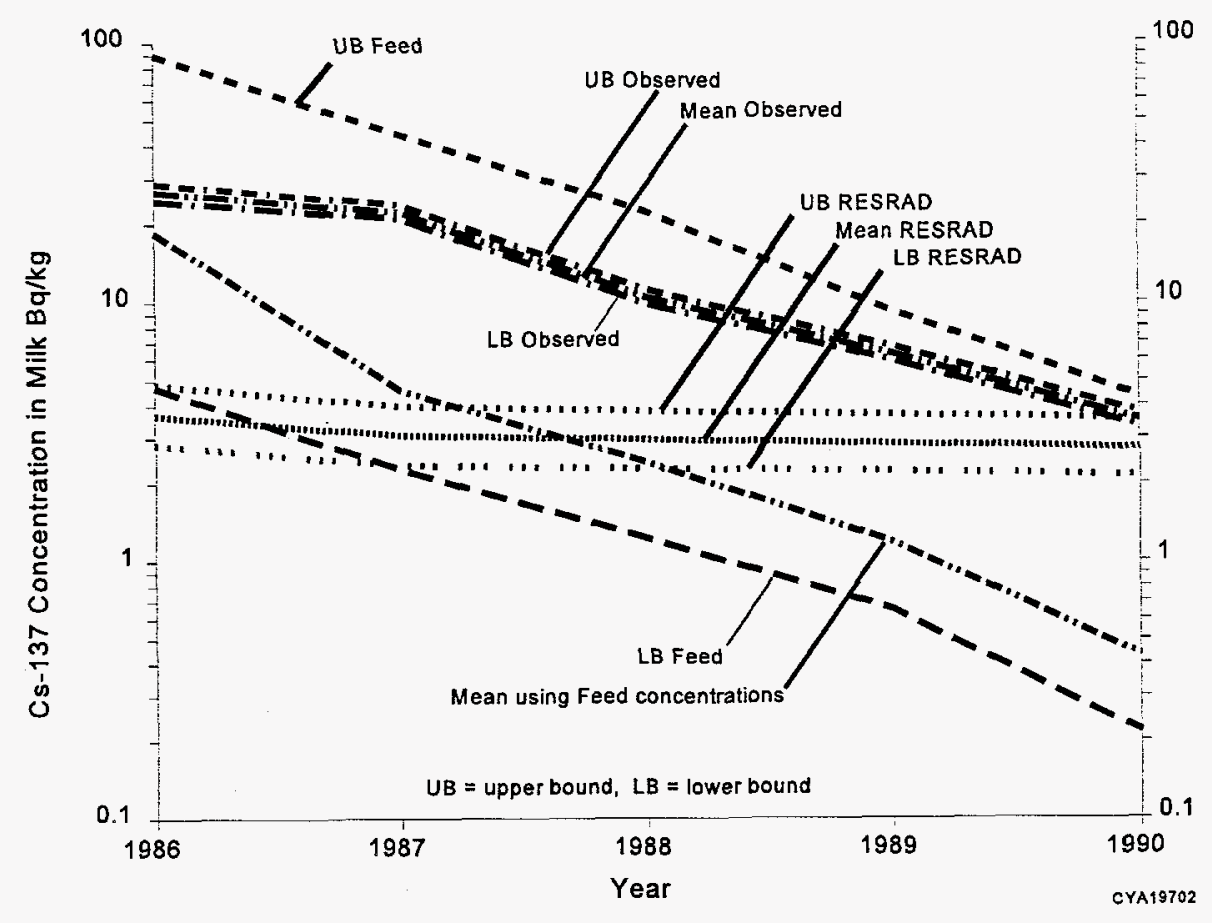

FIGURE 18 Comparison of Observed Cesium-137 Concentrations

in Milk with Estimates Based on Measured and RESRAD

Predicted Concentrations in Animal Feed

\subsubsection{Fish}

The RESRAD prediction of the cesium-137 content of fish agrees with the measured concentration in 1986, but is about one-fifth of the measured concentrations for the following four years. This result could be due to the reasons discussed here. RESRAD uses the equilibrium bioaccumulation factor; that is, the transfer factor used is simply the correlation coefficient between the equilibrium cesium-137 content of edible fish and the content in water (IAEA 1992a). In this scenario, the content in water falls with time. Thus, the amount of cesium in the fish includes the cesium accumulated when the water was richer in cesium. Assuming equilibrium with the water content at the time of observation will underpredict the content in fish in all but the first year. Secondly, the measurements included three classes of fish: nonpredatory, mixed-predatory, and predatory. The cesium-137 in nonpredatory fish increased in 1986 and then declined over the years (Saxén and Rantavaara 1987; Saxén 1990) ; the RESRAD predictions agreed with these measured values. The content in predatory fish lagged the concentration in water, as would be expected because of the time required to travel up the food chain. The countrywide (Finland) annual transfer factors (fish/water) for different years are given in Table 7 (Saxén and Koskelainen 1992). 
TABLE 7 Observed Countrywide Average Annual Transfer Factors in Finland

\begin{tabular}{|c|c|c|c|}
\hline \multirow[b]{2}{*}{ Year } & \multicolumn{3}{|c|}{$\begin{array}{l}\text { Annual Average Transfer Factor } \\
\left(\mathrm{Bq} \mathrm{kg}^{-1} \text { fish/ } / \mathrm{Bq} \mathrm{kg}^{-1} \text { water }\right)\end{array}$} \\
\hline & Nonpredatory & $\begin{array}{l}\text { Mixed- } \\
\text { Predatory }\end{array}$ & Predatory \\
\hline 1986 & 300 & 400 & 200 \\
\hline 1987 & 4,100 & 8,700 & 8,700 \\
\hline 1988 & 5,000 & 11,000 & 16,000 \\
\hline 1989 & 3,600 & 11,000 & 16,000 \\
\hline 1990 & 4,200 & 12,000 & 17,000 \\
\hline
\end{tabular}

Source: Saxén and Koskelainen 1992.

\subsubsection{Berries}

The root uptake factors for tomatoes (IAEA 1992a) were used to estimate the concentration in wild berries because the uptake factor for berries was not available. Comparison of these predictions with the measured values indicates that the uptake factor for berries is two orders of magnitude higher than that for tomatoes.

\subsubsection{Radiological Dose}

The RESRAD blind predictions of total dose compare very well with the dose estimated by STUK for the periods April 1986 to April 1987 and April 1986 to December 1990. However, the RESRAD prediction for the lifetime dose was 2.5 times the estimated value.

The RESRAD predictions for external dose are 1.5 to 4 times the estimated values. While the predicted and estimated inhalation doses from resuspension for the first year were comparable, the predictions for the periods April 1986 to December 1990 and April 1986 to lifetime were 10 to 40 times larger. The inhalation dose is four orders of magnitude lower than the total dose and hence does not affect the predictions of the total dose. The predictions for the dose due to ingestion are comparable to the estimated values. 


\subsubsection{Human Intake}

The blind predictions of cesium-137 intake of adults (male and female) for the first half of 1986 and the second half of 1990 are close to the estimated values; however, the predictions for the intermediate times are about a half to a third of the estimated values. The blind predictions for intake of a child are within a factor of 2 of the estimated value.

\subsubsection{Whole Body Concentration}

The blind predictions of adult whole body concentration compared very well with the STUK estimates. The STUK estimates for males are contained within the uncertainty of limits of the RESRAD predictions, as are those for females from 1986 to 1990 . The predictions for females in 1991 are almost twice the STUK estimates. The blind predictions for the whole body concentration of children are about twice the STUK estimates throughout the prediction period.

\subsection{POST-OBSERVATION MODELING}

After comparing the RESRAD predictions with the measured and estimated values, the following changes were made to the RESRAD inputs: The time fraction spent outdoors was increased from 0.05 to 0.15 ; the indoor shielding factor for external radiation was reduced from 0.7 to 0.4 ; the mass loading for inhalation was set to the RESRAD default value one year after the passage of the contaminated plume; the transfer factors for veal were used instead of those for beef; and the averaging scheme for the composite meat transfer factor was changed to the leaf uptake dominant scheme in Appendix B.

The revised RESRAD predictions for intake agreed with the STUK estimates for the 1986 intakes of adult males and females and for children. The predictions for the next four years were 2 to 4 times lower than the STUK estimates. The revised predictions for adult whole body concentration were lower than the STUK estimates, although the STUK estimates were within the RESRAD uncertainty limits. The revised predictions for the whole body concentration of children agreed very well with the STUK estimates.

The revised total dose predictions were within 0.6 to 1.5 times the STUK estimates. The revised predictions for external dose were 1 to 3 times the STUK estimates. The revised predictions for inhalation dose from resuspension were twice the STUK estimates. The revised predictions for the dose due to ingestion were comparable to the estimated values for the first year and for the period April 1986 to lifetime, while the predictions were 2.5 times lower than the estimates for the period April 1986 to December 1990. 


\subsection{SUGGESTIONS TO EXTEND THE CAPABILITY OF RESRAD}

This scenario included a wide range of animal and human feeds. As mentioned before, RESRAD considers one animal feed that is applicable to both the meat and milk pathway. The human food "meat" represents all the different meats consumed by man. The intake-to-animalproduct transfer factors in Table 6 vary widely, by up to a factor of 500 between the different meats. The types and quantities of feed consumed by the different animals also differed greatly (Table 4). The differences between the soil-to-edible-plant transfer factors for the different animal feeds, although not as great as the animal transfer factors, are also significant (Table 5). Foliage-to-food transfer factors (foliar deposition, sprinkler irrigation) for pasture differ from those for grains. Representing these widely differing animal feeds and meats by a single fodder and a single meat category requires rather involved approximate averaging schemes. If this averaging is to be done outside RESRAD it defeats the purpose of a stochastic code and also increases the likelihood of human error. Hence, it is necessary to allow for a number of animal products and animal feeds; three to four animal products and two to four animal feeds should be sufficient. Consideration should also be given to increasing the number of plant products for human consumption. The user should be able to input different values of soil-to-edible-plant transfer factors and foliage-to-food translocation factors for the plant products and the animal feeds.

\section{CONCLUSIONS}

From this exercise, we were able to apply RESRAD to predict, with uncertainties, media concentrations, body burdens, and doses for Scenario S. Being an equilibrium model, RESRAD calculates annual average media concentrations and mispredicted some of the dynamic media concentrations, especially in the early years after plume arrival. Although RESRAD is not specifically designed for this type of application, our experience indicated that, with proper selection of input parameters, the code can be used to predict media concentrations, especially for the later years after arrival of the plume. From this experience, we learned to predict media concentrations with uncertainties. We successfully incorporated a Monte Carlo LHS routine into RESRAD and extended RESRAD from a deterministic model to a probabilistic model.

This exercise provided a forum for international modelers to exchange modeling experience as well as for discussions on models and parameters used. Although Scenario $S$ is ended, the task of model validation is not finished. Additional data sets from different sites and for a wide variety of radionuclides still need to be tested. 


\section{REFERENCES}

IAEA. See International Atomic Energy Agency.

International Atomic Energy Agency, 1992a, IAEA 9th Draft Working Document, Handbook of Parameter Values for the Prediction of Radionuclide Transfer in Temperate Environments, Vienna, Austria.

International Atomic Energy Agency, 1992b, VAMP: Co-Ordinated Research Programme on Validation of Environmental Model Predictions; Multiple Pathways Assessment; Description of Test Scenario $S$, Commission of the European Communities, Vienna, Austria.

International Atomic Energy Agency, 1996, Validation of Models Using Chernobyl Fallout Data from Southern Finland; Scenario S; Second Report of the VAMP Multiple Pathways Assessment Working Group, IAEA-TECDOC-904, Waste Safety Section, Vienna, Austria.

Saxén, R., 1990, Radioactivity of Surface Water and Freshwater Fish in Finland in 1987, STUK-A77, Finnish Centre for Radiation and Nuclear Safety, Helsinki, Finland.

Saxén, R., and A. Rantavaara, 1987, Radioactivity of Fresh Water Fish in Finland after the Chernobyl Accident in 1986, STUK-A61, Finnish Centre for Radiation and Nuclear Safety, Helsinki, Finland.

Saxén, R., and U. Koskelainen, 1992, Radioactivity of Surface Water and Freshwater Fish in Finland in 1988-1990, STUK-A94, Finnish Centre for Radiation and Nuclear Safety, Helsinki, Finland.

Yu, C., et al., 1993. Manual for Implementing Residual Radioactive Material Guidelines Using RESRAD Version 5.0, ANL/EAD/LD-2, Argonne National Laboratory, Argonne, Ill., Sept. 
APPENDIX A:

SELECTED TABULAR INFORMATION FROM SCENARIO S DESCRIPTION 
APPENDIX A:

\section{SELECTED TABULAR INFORMATION FROM SCENARIO S DESCRIPTION}

Selected information from the description of Scenario S (IAEA 1992) that was used in this simulation is tabulated in this appendix. Also included are the results of some data manipulations that were necessary to transform the data into a form that could be used in RESRAD. 
TABLE A.1 Vertical Distribution of Cesium-137 in Uncultivated Soil at Different Soil Sites

\begin{tabular}{|c|c|c|c|c|c|}
\hline \multicolumn{2}{|c|}{1986} & \multicolumn{2}{|c|}{1987} & \multicolumn{2}{|c|}{1988} \\
\hline $\begin{array}{l}\text { Depth } \\
(\mathrm{cm})\end{array}$ & $\begin{array}{c}\text { Cumulative } \\
(\%)\end{array}$ & $\begin{array}{l}\text { Depth } \\
\text { (cm) }\end{array}$ & $\begin{array}{c}\text { Cumulative } \\
(\%)\end{array}$ & $\begin{array}{l}\text { Depth } \\
\text { (cm) }\end{array}$ & $\begin{array}{c}\text { Cumulative } \\
(\%)\end{array}$ \\
\hline 1.5 & 82.4 & 1.5 & 19.3 & 1.5 & 48.2 \\
\hline 3.5 & 96.6 & 3.0 & 42.3 & 3.0 & 80.8 \\
\hline \multirow[t]{2}{*}{7.0} & 100.0 & 4.5 & 66.9 & 4.5 & 87.7 \\
\hline & & 6.5 & 83.8 & 6.5 & 93.5 \\
\hline 2.5 & 89.6 & 9.5 & 95.0 & 9.5 & 100.0 \\
\hline 4.5 & 98.2 & 13.5 & 98.5 & & \\
\hline \multirow[t]{2}{*}{8.0} & 99.9 & 18.5 & 100.0 & 1.5 & 85.6 \\
\hline & & & & 3.0 & 97.7 \\
\hline 1.5 & 86.1 & 1.5 & 66.1 & 1.5 & 99.1 \\
\hline 3.0 & 94.5 & 3.0 & 92.9 & 6.5 & 99.7 \\
\hline 5.0 & 97.0 & 4.5 & 95.8 & 9.5 & 100.0 \\
\hline \multirow[t]{2}{*}{8.5} & 100.1 & 6.5 & 97.6 & & \\
\hline & & 9.5 & 99.0 & 1.5 & 80.5 \\
\hline 2.0 & 79.9 & 13.5 & 99.8 & 3.0 & 93.0 \\
\hline 4.0 & 99.5 & 18.5 & 100.0 & 5.5 & 97.7 \\
\hline \multirow[t]{2}{*}{6.0} & 100.1 & & & 7.5 & 99.6 \\
\hline & & 1.5 & 54.9 & 10.5 & 100.0 \\
\hline 2.0 & 9.1 & 3.0 & 89.2 & & \\
\hline 4.5 & 17.1 & 5.0 & 94.8 & 1.5 & 44.0 \\
\hline \multirow[t]{2}{*}{7.5} & 18.7 & 6.5 & 96.6 & 3.0 & 96.0 \\
\hline & & 9.5 & 97.7 & 4.5 & 97.7 \\
\hline 3.0 & 68.9 & 13.5 & 98.9 & 6.5 & 99.1 \\
\hline 6.0 & 89.7 & 17.0 & 100.0 & 9.5 & 99.6 \\
\hline \multirow[t]{2}{*}{8.5} & 100.0 & & & 13.5 & 99.8 \\
\hline & & 1.5 & 62.2 & 17.5 & 100.0 \\
\hline 1.5 & 4.1 & 3.0 & 82.8 & & \\
\hline 3.5 & 12.8 & 4.5 & 93.5 & 1.5 & 79.6 \\
\hline 6.5 & 15.7 & 6.5 & 98.3 & 3.5 & 96.6 \\
\hline \multirow[t]{2}{*}{9.0} & 20.0 & 9.5 & 99.1 & 5.5 & 100.0 \\
\hline & & 13.5 & 99.5 & & \\
\hline 1.0 & 90.5 & 18.5 & 99.9 & 1.5 & 55.3 \\
\hline 2.0 & 97.1 & 22.5 & 100.1 & 3.0 & 86.5 \\
\hline 4.0 & 98.9 & & & 4.5 & 93.6 \\
\hline \multirow[t]{2}{*}{7.5} & 100.0 & 1.5 & 71.3 & 6.5 & 100.0 \\
\hline & & 3.0 & 85.0 & & \\
\hline 2.0 & 71.8 & 4.5 & 85.0 & 1.5 & 37.6 \\
\hline 4.0 & 82.5 & 6.5 & 92.2 & 3.5 & 75.3 \\
\hline 6.0 & 89.4 & 10.5 & 97.1 & 5.5 & 82.6 \\
\hline \multirow[t]{2}{*}{8.5} & 100.1 & 15.5 & $98: 7$ & 7.5 & 86.4 \\
\hline & & 19.5 & 100.0 & 10.5 & 89.2 \\
\hline 1.0 & 71.0 & & & 14.5 & 94.6 \\
\hline 2.5 & 93.0 & 1.5 & 32.4 & 18.5 & 99.0 \\
\hline 5.5 & 97.1 & 3.0 & 55.5 & 22.5 & 100.0 \\
\hline \multirow[t]{2}{*}{8.5} & 100.1 & 4.5 & 67.9 & & \\
\hline & & 6.5 & 78.3 & 1.5 & 54.5 \\
\hline 2.0 & 92.2 & 9.5 & 88.1 & 3.0 & 93.5 \\
\hline 4.0 & 95.4 & 13.5 & 95.2 & 4.5 & 98.0 \\
\hline 6.5 & 97.7 & 18.5 & 100.0 & 6.5 & 99.4 \\
\hline 10.0 & 99.9 & & & 9.5 & 100.0 \\
\hline 2.0 & 30.1 & & & & \\
\hline 5.0 & 78.0 & & & & \\
\hline 8.0 & 97.2 & & & & \\
\hline 11.0 & 98.8 & & & & \\
\hline 13.0 & 99.9 & & & & \\
\hline 2.0 & 23.4 & & & & \\
\hline 5.0 & 79.8 & & & & \\
\hline 8.0 & 98.5 & & & & \\
\hline 11.0 & 99.7 & & & & \\
\hline 13.0 & 100.3 & & & & \\
\hline
\end{tabular}


TABLE A.1 (Cont.)

\begin{tabular}{|c|c|c|c|c|c|c|c|}
\hline \multicolumn{2}{|c|}{1989} & \multicolumn{2}{|c|}{1989 (cont.) } & \multicolumn{2}{|c|}{1989 (cont.) } & \multicolumn{2}{|c|}{1989 (cont.) } \\
\hline $\begin{array}{l}\text { Depth } \\
\text { (cm) }\end{array}$ & $\begin{array}{c}\text { Cumulative } \\
(\%)\end{array}$ & $\begin{array}{l}\text { Depth } \\
\text { (cm) }\end{array}$ & $\begin{array}{c}\text { Cumulative } \\
(\%)\end{array}$ & $\begin{array}{l}\text { Depth } \\
(\mathrm{cm})\end{array}$ & $\begin{array}{c}\text { Cumulative } \\
(\%)\end{array}$ & $\begin{array}{l}\text { Depth } \\
\text { (cm) }\end{array}$ & $\begin{array}{c}\text { Cumulative } \\
\text { (\%) }\end{array}$ \\
\hline 1.0 & 20.2 & 1.5 & 39.5 & 1.5 & 67.4 & 0.0 & 80.6 \\
\hline 3.0 & 68.2 & 3.0 & 56.8 & 3.0 & 88.5 & 1.5 & 91.8 \\
\hline 5.0 & 85.2 & 4.5 & 60.4 & 4.5 & 94.0 & 3.0 & 96.8 \\
\hline 7.0 & 94.3 & 6.5 & 63.6 & 6.5 & 96.3 & 4.5 & 97.9 \\
\hline \multirow[t]{2}{*}{12.0} & 100.0 & 9.5 & 65.9 & 9.5 & 97.6 & 6.5 & 98.4 \\
\hline & & 12.0 & 66.7 & 13.5 & 98.7 & 28.0 & 99.9 \\
\hline 1.0 & 5.8 & & & 25.0 & 100.0 & & \\
\hline 3.5 & 59.8 & 0.0 & 26.4 & & & 1.5 & 50.5 \\
\hline 5.5 & 79.6 & 1.5 & 72.3 & 0.0 & 55.6 & 3.0 & 75.9 \\
\hline 8.0 & 92.1 & 3.0 & 87.4 & 1.5 & 67.5 & 4.5 & 89.4 \\
\hline 10.0 & 98.1 & 6.5 & 93.4 & 3.0 & 77.0 & 6.5 & 95.8 \\
\hline \multirow[t]{2}{*}{12.2} & 99.9 & 9.5 & 98.4 & 4.5 & 82.1 & 13.0 & 100.0 \\
\hline & & 13.5 & 99.3 & 6.5 & 86.1 & & \\
\hline 1.0 & 18.7 & 15.0 & 100.1 & 9.5 & 90.1 & 2.0 & 87.7 \\
\hline 3.0 & 76.3 & & & 13.5 & 95.0 & 3.5 & 94.5 \\
\hline 5.0 & 89.3 & 1.5 & 84.1 & 24.0 & 100.1 & 5.0 & 96.6 \\
\hline 7.0 & 94.8 & 3.0 & 94.7 & & & 8.0 & 98.7 \\
\hline 12.0 & 97.6 & 4.5 & 98.0 & 1.5 & 57.0 & 13.5 & 100.0 \\
\hline 17.0 & 98.2 & 13.0 & 100.0 & 3.0 & 76.3 & & \\
\hline 22.0 & 99.2 & & & 4.5 & 84.7 & 0.0 & 56.5 \\
\hline \multirow[t]{2}{*}{28.0} & 100.1 & 1.5 & 84.4 & 6.5 & 91.2 & 1.5 & 80.5 \\
\hline & & 3.0 & 92.9 & 9.5 & 93.7 & 3.0 & 88.8 \\
\hline 1.0 & 55.2 & 4.5 & 97.9 & 13.5 & 97.6 & 4.0 & 95.5 \\
\hline 3.0 & 80.4 & 11.5 & 100.0 & 25.0 & 100.0 & 6.5 & 98.1 \\
\hline 5.0 & 87.7 & & & & & 13.5 & 100.1 \\
\hline 8.5 & 94.5 & 0.0 & 72.2 & 1.5 & 73.4 & & \\
\hline \multirow[t]{2}{*}{17.5} & 100.0 & 1.5 & 81.2 & 3.0 & 93.6 & 1.5 & 45.0 \\
\hline & & 3.0 & 89.6 & 4.5 & 96.6 & 3.0 & 69.5 \\
\hline 1.0 & 53.7 & 4.5 & 95.7 & 6.5 & 98.0 & 4.5 & 79.8 \\
\hline 2.0 & 84.9 & 10.5 & 100.0 & 9.5 & 99.2 & 6.5 & 85.9 \\
\hline 10.0 & 99.2 & & & 14.0 & 100.1 & 9.5 & 95.2 \\
\hline \multirow[t]{2}{*}{15.0} & 100.0 & 0.0 & 65.5 & & & 16.5 & 99.9 \\
\hline & & 1.5 & 84.0 & 0.0 & 22.0 & & \\
\hline 1.5 & 22.3 & 3.0 & 89.2 & 4.5 & 96.3 & 2.0 & 70.7 \\
\hline 3.0 & 62.0 & 4.5 & 92.6 & 6.5 & 99.1 & 3.5 & 82.8 \\
\hline 4.5 & 84.2 & 6.5 & 95.6 & 14.5 & 100.0 & 5.0 & 87.7 \\
\hline 6.5 & 93.9 & 14.5 & 98.3 & & & 8.0 & 91.3 \\
\hline 9.5 & 97.9 & 19.5 & 98.6 & 0.0 & 65.5 & 13.5 & 100.1 \\
\hline \multirow[t]{2}{*}{14.5} & 99.9 & 22.5 & 100.1 & 1.5 & 92.1 & & \\
\hline & & & & 3.5 & 96.2 & 1.5 & 35.3 \\
\hline 1.5 & 39.2 & 0.0 & 37.6 & 4.5 & 97.9 & 3.0 & 58.4 \\
\hline 3.0 & 78.8 & 1.5 & 67.6 & 10.0 & 99.0 & 4.5 & 72.4 \\
\hline 4.5 & 91.5 & 3.0 & 89.9 & 16.0 & 100.1 & 6.5 & 84.1 \\
\hline 6.5 & 97.6 & 4.5 & 96.1 & & & 9.5 & 92.2 \\
\hline 9.5 & 99.6 & 6.5 & 97.8 & 1.5 & 61.7 & 13.0 & 100.0 \\
\hline \multirow[t]{2}{*}{13.0} & 100.0 & 9.5 & 98.9 & 3.0 & 84.1 & & \\
\hline & & 13.5 & 99.6 & 4.5 & 96.4 & 1.5 & 76.8 \\
\hline 1.5 & 39.9 & 24.0 & 99.9 & 10.0 & 99.1 & 3.0 & 93.7 \\
\hline 3.0 & 74.7 & & & 16.0 & 99.7 & 4.5 & 97.9 \\
\hline 4.5 & 88.8 & 1.5 & 84.7 & 20.0 & 100.0 & 11.5 & 100.1 \\
\hline 6.5 & 95.6 & 3.0 & 96.3 & & & & \\
\hline \multirow[t]{2}{*}{14.5} & 100.0 & 4.5 & 97.7 & 1.5 & 87.5 & 1.5 & 79.6 \\
\hline & & 6.5 & 98.6 & 3.0 & 94.2 & 3.0 & 92.7 \\
\hline 1.5 & 51.8 & 9.5 & 99.6 & 4.5 & 96.4 & 4.5 & 95.1 \\
\hline 3.0 & 91.5 & 13.5 & 99.8 & 6.5 & 98.3 & 6.5 & 96.9 \\
\hline 4.5 & 97.2 & 22.5 & 100.1 & 14.5 & 99.0 & 9.5 & 98.0 \\
\hline \multirow[t]{2}{*}{13.0} & 100.0 & & & 19.5 & 99.6 & 16.5 & 100.1 \\
\hline & & & & 24.0 & 100.0 & & \\
\hline 1.5 & 3.5 & & & & & & \\
\hline 3.0 & 59.5 & & & & & & \\
\hline 4.5 & 82.9 & & & & & & \\
\hline 6.5 & 98.2 & & & & & & \\
\hline 12.0 & 100.1 & & & & . & & \\
\hline
\end{tabular}


TABLE A.2 Areal Deposition of Cesium-137 in the Test Region

\begin{tabular}{|c|c|c|c|c|c|}
\hline \multirow[b]{2}{*}{$\begin{array}{c}\text { Region } \\
\text { POP\# }\end{array}$} & \multirow[b]{2}{*}{$\begin{array}{l}\text { Total } \\
\text { Area } \\
\left(\mathrm{km}^{2}\right)\end{array}$} & \multirow[b]{2}{*}{$\begin{array}{c}\text { Land } \\
\text { Area } \\
\left(\mathrm{km}^{2}\right) \\
\end{array}$} & \multirow[b]{2}{*}{$\begin{array}{c}\text { Areal } \\
\text { Average } \\
\left(\mathrm{kBq} \mathrm{m}^{-2}\right)\end{array}$} & \multicolumn{2}{|c|}{ Total Deposition } \\
\hline & & & & $\begin{array}{c}\text { Land/Water } \\
(\mathrm{TBq})\end{array}$ & $\begin{array}{r}\text { Land } \\
(\mathrm{TBq})\end{array}$ \\
\hline 1 & 19,802 & 17,010 & 39.5 & 782 & 672 \\
\hline 2 & 19,357 & 16,230 & 29.9 & 579 & 485 \\
\hline 3 & 19,956 & 16,511 & 11.4 & 227 & 188 \\
\hline 4 & 12,828 & 10,783 & 18.1 & 232 & 195 \\
\hline 5 & 21,660 & 16,342 & 16.6 & 360 & 271 \\
\hline 6 & 21,585 & 17,782 & 2.3 & 50 & 41 \\
\hline 7 & 23,166 & 22,170 & 22.3 & 517 & 494 \\
\hline 8 & 10,404 & 9,898 & 13.6 & 141 & 135 \\
\hline 9 & 27,319 & 26,447 & 23.2 & 634 & 614 \\
\hline Sum & 176,077 & 153,173 & - & 3,522 & 3,095 \\
\hline \multicolumn{4}{|c|}{ Average deposition $\left(\mathrm{kBq} \mathrm{m}^{-2}\right)$} & 20.0 & 20.2 \\
\hline
\end{tabular}

\begin{tabular}{crrr|rrrr}
\hline $\begin{array}{l}\text { Region } \\
\text { AGR\# }\end{array}$ & $\begin{array}{r}\text { Land } \\
\text { Area } \\
\left(\mathrm{km}^{2}\right)\end{array}$ & $\begin{array}{c}\text { Areal } \\
\text { Average } \\
\left(\mathrm{kBq} \mathrm{m}^{-2}\right)\end{array}$ & $\begin{array}{r}\text { Total } \\
(\mathrm{TBq})\end{array}$ & $\begin{array}{rlrlr}\text { Region } \\
\text { FISH\# }\end{array}$ & $\begin{array}{r}\text { Land } \\
\text { Area } \\
\left(\mathrm{km}^{2}\right)\end{array}$ & $\begin{array}{c}\text { Areal } \\
\text { Average } \\
\left(\mathrm{kBq} \mathrm{m}^{-2}\right)\end{array}$ & $\begin{array}{r}\text { Total } \\
(\mathrm{TBq})\end{array}$ \\
\hline 1 & 5,676 & 6.2 & 35 & 1 & 11,753 & 14.2 & 167 \\
2 & 14,512 & 25.7 & 373 & 2 & 9,866 & 13.1 & 129 \\
3 & 3,075 & 3.8 & 12 & 3 & 57,192 & 6.8 & 389 \\
4 & 6,861 & 26.0 & 178 & 4 & 38,823 & 30.2 & 1172 \\
5 & 5,715 & 43.8 & 250 & 5 & 28,032 & 34.4 & 964 \\
6 & 6,889 & 14.5 & 100 & 6 & 30,426 & 22.5 & 685 \\
7 & 14,883 & 27.8 & 414 & Sum & 176,092 & - & 3,506 \\
8 & 16,511 & 11.4 & 188 & & & & \\
9 & 5,106 & 33.5 & 171 & & & & \\
10 & 14,431 & 13.9 & 201 & & & & \\
11 & 4,551 & 7.7 & 35 & & & & \\
12 & 9,363 & 46.6 & 436 & & & & \\
13 & 17,782 & 2.3 & 41 & & & & \\
14 & 10,502 & 25.6 & 269 & & & & \\
15 & 5,346 & 18.5 & 99 & & & & \\
16 & 8,446 & 16.4 & 139 & & & & \\
17 & 6,976 & 22 & 153 & & & & \\
Sum & 15,6633 & - & 3,094 & & & & \\
\hline
\end{tabular}




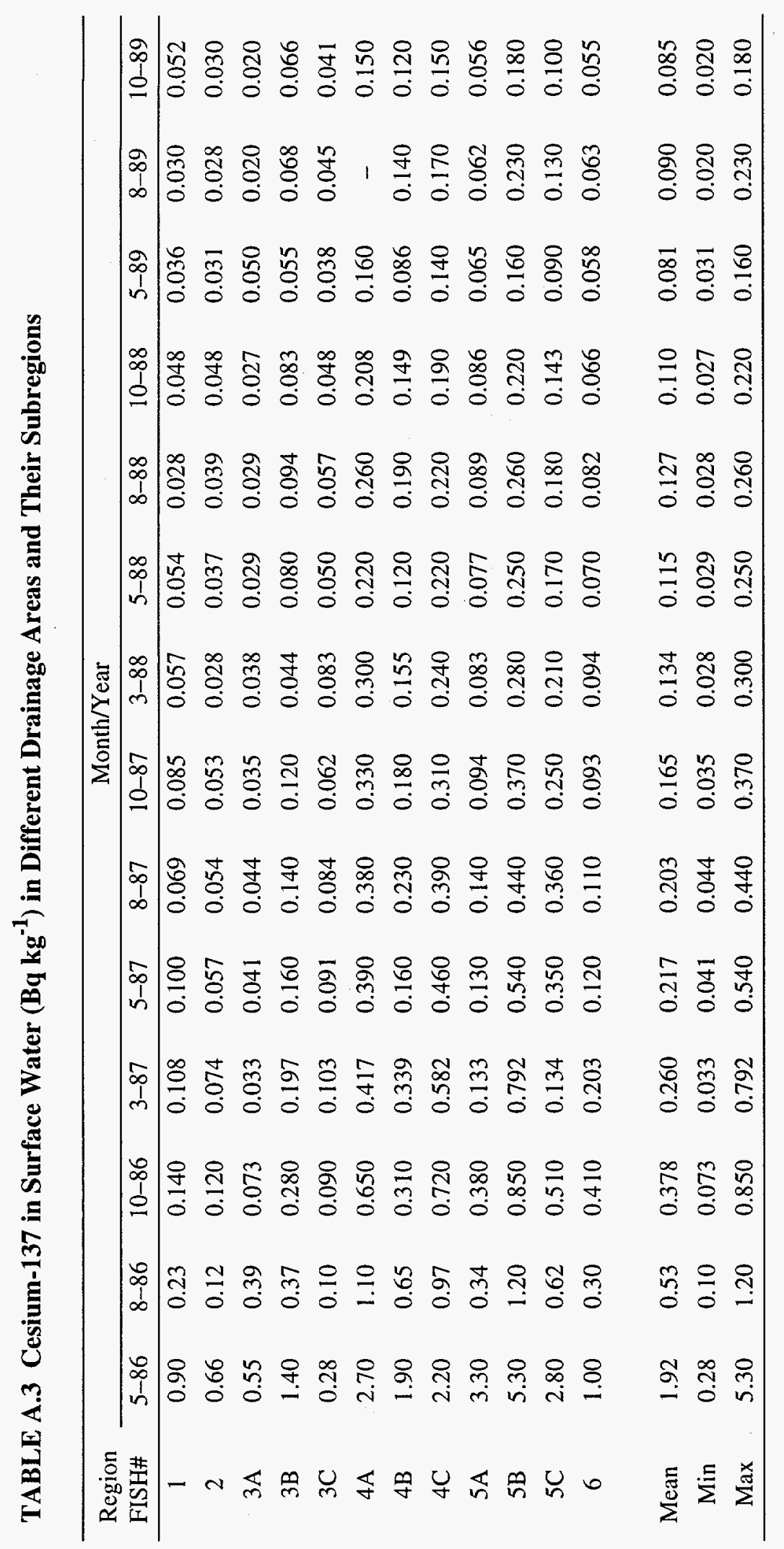


TABLE A.4 Human Food Consumption Rates (Scenario S)

\begin{tabular}{|c|c|c|c|}
\hline Foodstuff & $\begin{array}{l}\text { Woman } \\
\left(\mathrm{g} \mathrm{d}^{-1}\right)\end{array}$ & $\begin{array}{c}\text { Man } \\
\left(\mathrm{g} \mathrm{d}^{-1}\right) \\
\end{array}$ & $\begin{array}{l}\text { Child }^{\mathrm{a}} \\
\left(\mathrm{g} \mathrm{d}^{-1}\right)\end{array}$ \\
\hline Rye & 42 & 58 & - \\
\hline Wheat & 109 & 135 & - \\
\hline Other cereals & 28 & 38 & 168 \\
\hline Potato & 150 & 210 & 136 \\
\hline Fruit veg. & 48 & 40 & - \\
\hline Root veg. & 50 & 50 & 49.3 \\
\hline Pea, bean & 10 & 10 & - \\
\hline Fruit & 275 & 225 & 225 \\
\hline Berries, garden & 43 & 43 & - \\
\hline Berries, wild & 9 & 9 & - \\
\hline Wild mushrooms & 3.6 & 3.6 & - \\
\hline Leafy veg. & 45 & 35 & 49.3 \\
\hline Milk & 570 & 870 & 752 \\
\hline Cheese & 33 & 35 & - \\
\hline Beef & 49 & 64 & 125 \\
\hline Pork & 54 & 88 & - \\
\hline Poultry & 16 & 16 & - \\
\hline Game & 3.4 & 4.2 & - \\
\hline Egg & 25 & 34 & 21 \\
\hline Fish, freshwater & 10 & 15 & 13.7 \\
\hline
\end{tabular}

$\mathrm{a}_{-}=$not specified in the scenario description. 
TABLE A.5 Feed Utilization of Dairy Cows by the Type of Feed in 1988

\begin{tabular}{|c|c|c|c|c|c|c|c|c|c|}
\hline \multirow[b]{2}{*}{$\begin{array}{c}\text { Agriculture } \\
\text { Area }\end{array}$} & \multicolumn{7}{|c|}{ Specified Feed Utilization $(\mathrm{kg})$} & \multicolumn{2}{|c|}{ RESRAD Input (kg) } \\
\hline & Silage & Hay & Pasture & Grain & $\begin{array}{l}\text { Complete } \\
\text { Feed }\end{array}$ & $\begin{array}{c}\text { Feed } \\
\text { Concentrate }\end{array}$ & Others & Fodder & Grain \\
\hline AGR1 & 5,657 & 1,241 & 6,370 & 1,312 & 210 & 227 & 711 & 13,268 & 2,460 \\
\hline AGR2 & 7,188 & 882 & 6,123 & 938 & 552 & 187 & 605 & 14,193 & 2,282 \\
\hline AGR3 & 6,615 & 1,322 & 3,900 & 1,119 & 834 & 319 & 1,081 & 11,837 & 3,353 \\
\hline AGR4 & 5,771 & 1,276 & 5,792 & 1,295 & 293 & 260 & 969 & 12,839 & 2,817 \\
\hline AGR5 & 6,376 & 1,019 & 6,526 & 1,133 & 342 & 193 & 1,025 & 13,921 & 2,693 \\
\hline AGR6 & 7,516 & 827 & 5,454 & 867 & 814 & 191 & 459 & 13,797 & 2,331 \\
\hline AGR7 & 6,836 & 1,081 & 6,390 & 780 & 691 & 171 & 398 & 14,307 & 2,040 \\
\hline AGR8 & 8,247 & 869 & 6,513 & 831 & 571 & 204 & 230 & 15,629 & 1,836 \\
\hline AGR9 & 5,242 & 1,426 & 5,909 & 1,277 & 207 & 202 & 482 & 12,577 & 2,168 \\
\hline AGR10 & 6,968 & 1,008 & 6,448 & 965 & 497 & 173 & 403 & 14,424 & 2,038 \\
\hline AGR11 & 5,550 & 1,553 & 4,505 & 1,665 & 140 & 244 & 392 & $-^{a}$ & - \\
\hline AGR12 & 6,161 & 1,217 & 6,273 & 1,230 & 326 & 221 & 493 & 13,651 & 2,270 \\
\hline AGR13 & 6,924 & 1,104 & 6,364 & 996 & 439 & 199 & 308 & 14,392 & 1,942 \\
\hline AGR14 & 5,718 & 1,263 & 6,182 & 990 & 515 & 166 & 510 & 13,163 & 2,181 \\
\hline AGR15 & 5,664 & 1,331 & 5,408 & 1,502 & 207 & 221 & 610 & 12,403 & 2,540 \\
\hline AGR16 & 4,775 & 1,461 & 5,304 & 1,375 & 264 & 300 & 874 & 11,540 & 2,813 \\
\hline AGR17 & 6,464 & 1,311 & 3,673 & 1,221 & 571 & 273 & 549 & 11,448 & 2,614 \\
\hline Average & 6,334 & 1,188 & 5,714 & 1,147 & 440 & 221 & 594 & 13,337 & 2,399 \\
\hline $\begin{array}{l}\text { Standard } \\
\text { Deviation }\end{array}$ & 893 & 215 & 906 & 245 & 215 & 45 & 254 & 1,174 & 393 \\
\hline Per day & 17.35 & 3.25 & 15.65 & 3.14 & 1.20 & 0.60 & 1.63 & 36.54 & 6.57 \\
\hline
\end{tabular}

$a_{-}=$AGR11 was not used because of lack of beef cattle data in Table A.6. 
TABLE A.6 Feed Utilization of Beef Cattle by the Type of Feed in $1988^{\mathrm{a}}$

\begin{tabular}{|c|c|c|c|c|c|c|c|c|c|}
\hline \multirow[b]{2}{*}{$\begin{array}{c}\text { Agriculture } \\
\text { Area }\end{array}$} & \multicolumn{7}{|c|}{ Specified Feed Utilization $(\mathrm{kg})$} & \multicolumn{2}{|c|}{ RESRAD Input $(\mathrm{kg})$} \\
\hline & Silage & Hay & Pasture & Grain & $\begin{array}{l}\text { Complete } \\
\text { Feed }\end{array}$ & $\begin{array}{c}\text { Feed } \\
\text { Concentrate }\end{array}$ & Others & Fodder & Grain \\
\hline AGR 1 & 1,474 & 847 & 1,209 & 1,009 & 78 & 42 & 196 & 3,530 & 1,325 \\
\hline AGR2 & 2,155 & 466 & 2,854 & 727 & 146 & 33 & 521 & 5,475 & 1,427 \\
\hline AGR3 & 813 & 761 & 605 & 1,057 & 198 & 63 & 778 & 2,178 & 2,096 \\
\hline AGR4 & 1,865 & 823 & 1,326 & 903 & 87 & 69 & 442 & 4,014 & 1,502 \\
\hline AGR5 & 1,474 & 686 & 2,360 & 920 & 103 & 55 & 347 & 4,520 & 1,425 \\
\hline AGR6 & 2,627 & 517 & 1,905 & 690 & 216 & 50 & 280 & 5,049 & 1,235 \\
\hline AGR7 & 2,186 & 596 & 2,789 & 706 & 162 & 33 & 95 & 5,571 & 996 \\
\hline AGR8 & 2,917 & 592 & 2,379 & 613 & 209 & 36 & 67 & 5,888 & 925 \\
\hline AGR9 & 1,084 & 946 & 1,079 & 1,049 & 47 & 62 & 224 & 3,109 & 1,382 \\
\hline AGR10 & 1,997 & 601 & 2,412 & 716 & 177 & 35 & 168 & 5,009 & 1,096 \\
\hline AGR11 & - & - & - & - & - & - & - & - & - \\
\hline AGR 12 & 1,355 & 891 & 1,339 & 937 & 92 & 67 & 213 & 3,585 & 1,310 \\
\hline AGR 13 & 1,928 & 700 & 2,412 & 751 & 154 & 47 & 168 & 5,039 & 1,121 \\
\hline AGR14 & 1,436 & 777 & 1,612 & 882 & 184 & 41 & 291 & 3,825 & 1,398 \\
\hline AGR15 & 1,430 & 909 & 1,528 & 1,051 & 23 & 85 & 179 & 3,866 & 1,338 \\
\hline AGR16 & 1,266 & 772 & 1,547 & 1,003 & 72 & 84 & 426 & 3,586 & 1,584 \\
\hline AGR17 & 1,222 & 576 & 2,067 & 876 & 95 & 88 & - & 3,866 & 1,058 \\
\hline Average & 1,702 & 716 & 1,839 & 868 & 128 & 56 & 293 & 4,257 & 1,326 \\
\hline $\begin{array}{l}\text { Standard } \\
\text { Deviation }\end{array}$ & 571 & 147 & 656 & 148 & 60 & 19 & 186 & 1,013 & 278 \\
\hline Per day & 4.66 & 1.96 & 5.04 & 2.38 & 0.35 & 0.15 & 0.80 & 11.66 & 3.63 \\
\hline
\end{tabular}

a $-=$ not specified in scenario description. 


\section{REFERENCE FOR APPENDIX A}

International Atomic Energy Agency, 1992, VAMP: Co-Ordinated Research Programme on Validation of Experimental Model Predictions; Multiple Pathways Assessment; Description of Scenario $S$, Commission of the European Communities, Vienna, Austria. 


\section{APPENDIX B:}

CALCULATION OF COMPOSITE LIVESTOCK FEED INTAKE RATES AND COMPOSITE TRANSFER FACTORS FOR THE HUMAN CESIUM-137 INTAKE, RADIOLOGICAL DOSE, AND BODY BURDEN RUNS 



\section{APPENDIX B:}

\section{CALCULATION OF COMPOSITE LIVESTOCK FEED INTAKE RATES AND COMPOSITE TRANSFER FACTORS FOR THE HUMAN CESIUM-137 INTAKE, RADIOLOGICAL DOSE, AND BODY BURDEN RUNS}

The composite soil-to-plant (root uptake) transfer factor for nonleafy vegetables was the weighted average of the root uptake transfer factors, $\mathrm{RTF}_{\mathrm{i}}$, of all the nonleafy vegetables, the weights being proportional to the human consumption rates, $C_{i}$, of the different food item in this class:

$$
\begin{aligned}
\mathrm{C}_{\text {nonleafy }}= & \mathrm{C}_{\text {barley }}+\mathrm{C}_{\text {oats }}+\mathrm{C}_{\text {rye }}+\mathrm{C}_{\text {wheat }}+\mathrm{C}_{\text {pea,bean }}+\mathrm{C}_{\text {potato }}+\mathrm{C}_{\text {root }}+\mathrm{C}_{\text {fruit }}, \\
\mathrm{RTF}_{\text {nonleafy }}= & \left(\mathrm{RTF}_{\text {barley }} * \mathrm{C}_{\text {barley }}+\mathrm{RTF}_{\text {oats }} * \mathrm{C}_{\text {oats }}+\mathrm{RTF}_{\text {rye }} * \mathrm{C}_{\text {rye }}+\mathrm{RTF}_{\text {wheat }} * \mathrm{C}_{\text {wheat }}\right. \\
& \left.+\mathrm{RTF}_{\text {pea,bean }} * \mathrm{C}_{\text {pea,bean }}+\mathrm{RTF}_{\text {potato }} * \mathrm{C}_{\text {potato }}+\mathrm{RTF}_{\text {root }} * \mathrm{C}_{\text {root }}+\mathrm{RTF}_{\text {fruit }} * \mathrm{C}_{\text {fruit }}\right) / \mathrm{C}_{\text {nonleafy }}, \\
\mathrm{RTF}_{\text {nonleafy }}= & \mathrm{RTF}_{\text {barley }} * 0.02+\mathrm{RTF}_{\text {oats }} * 0.02+\mathrm{RTF}_{\text {rye }} * 0.06+\mathrm{RTF}_{\text {wheat }} * 0.15 \\
& +\mathrm{RTF}_{\text {pea,bean }} * 0.01+\mathrm{RTF}_{\text {potato }} * 0.23+\mathrm{RTF}_{\text {root }} * 0.44+\mathrm{RTF}_{\text {fruit }} * 0.06
\end{aligned}
$$

The composite soil-to-plant (root uptake) transfer factor for "fodder" was based on the feed consumption characteristics, $\mathrm{CD}_{\mathbf{i}}$, of the dairy cows and was computed as follows:

$$
\begin{aligned}
& \mathrm{CD}_{\text {fodder }}=\mathrm{CD}_{\text {barley }}+\mathrm{CD}_{\text {oats }}+\mathrm{CD}_{\text {pasture }}, \\
& \mathrm{RTF}_{\text {fodder }}=\left(\mathrm{RTF}_{\text {barley }} * \mathrm{CD}_{\text {barley }}+\mathrm{RTF}_{\text {oats }} * \mathrm{CD}_{\text {oats }}+\mathrm{RTF}_{\text {pasture }} * \mathrm{CD}_{\text {pasture }}\right) / \mathrm{CD}_{\text {fodder }}, \\
& \mathrm{RTF}_{\text {fodder }}=\mathrm{RTF}_{\text {barley }} * 0.09+\mathrm{RTF}_{\text {oats }} * 0.06+\mathrm{RTF}_{\text {pasture }} * 0.85
\end{aligned}
$$

The composite intake-to-edible "meat" transfer factor, $\mathrm{IMF}_{\text {meat }}$, was computed using the expression

$$
\begin{aligned}
\mathrm{C}_{\text {meat }} & =\mathrm{C}_{\text {beef }}+\mathrm{C}_{\text {pork }}+\mathrm{C}_{\text {poultry }}+\mathrm{C}_{\text {eggs }}, \\
\mathrm{IMF}_{\text {meat }} & =\left(\mathrm{IMF}_{\text {beef }} * \mathrm{C}_{\text {beef }}+\mathrm{IMF}_{\text {pork }} * \mathrm{C}_{\text {pork }}+\mathrm{IMF}_{\text {poultry }} * \mathrm{C}_{\text {poultry }}+\mathrm{MMF}_{\text {eggs }} * \mathrm{C}_{\text {eggs }}\right) / \mathrm{C}_{\text {meat }}, \\
\mathrm{IMF}_{\text {meat }} & =\mathrm{IMF}_{\text {beef }} * 0.33+\mathrm{IMF}_{\text {pork }} * 0.41+\mathrm{IMF}_{\text {poultry }} * 0.09+\mathrm{IMF}_{\text {eggs }} * 0.17 .
\end{aligned}
$$

The water intake for meat depends on the water intake, $\mathrm{W}_{\mathrm{i}}$, of the different livestock products, the human consumption rates of these products, and the composite meat transfer factor above: 


$$
\begin{aligned}
& \mathrm{W}_{\text {meat }}=\frac{\mathrm{W}_{\text {beef }} * \mathrm{IMF}_{\text {beef }} * \mathrm{C}_{\text {beef }}+\mathrm{W}_{\text {pork }} * \mathrm{IMF}_{\text {pork }} * \mathrm{C}_{\text {pork }}+\mathrm{W}_{\text {poultry }} * \mathrm{IMF}_{\text {poultry }} * \mathrm{C}_{\text {poultry }}+\mathrm{W}_{\text {eggs }} * \mathrm{IMF}_{\text {eggs }} * \mathrm{C}_{\text {eggs }}}{\mathrm{IMF}_{\text {meat }} * \mathrm{C}_{\text {meat }}}, \\
& \mathrm{W}_{\text {meat }}=\left(50 * \mathrm{IMF}_{\text {beef }} * 0.33+8 * \mathrm{IMF}_{\text {pork }} * 0.41+0.25 * \mathrm{IMF}_{\text {poultry }} * 0.09+0.25 * \mathrm{IMF}_{\text {eggs }} * 0.17\right) / \mathrm{IMF}_{\text {meat }}
\end{aligned}
$$

The fodder intake rate for meat, $\mathrm{F}_{\text {meat }}$, used in the initial (blind) predictions is a two-way weighted average of the different animal feeds, $F_{i}$, the two weights being the human consumption rates of the different meat products and the root uptake transfer factor. The expression used is,

$$
\begin{aligned}
& \mathrm{F}_{\text {meat }}=\frac{\sum_{\text {beef }}+\sum_{\text {pork }}+\sum_{\text {poultry }}+\sum_{\text {eggs }}}{\mathrm{RTF}_{\text {fodder }} * \mathrm{C}_{\text {meat }}}, \\
& \sum_{\text {beef }}=\left(\mathrm{F}_{\text {pasture }}^{\text {beef }} * \mathrm{RTF}_{\text {pasture }}+\mathrm{F}_{\text {barley }}^{\text {beef }} * \mathrm{RTF}_{\text {barley }}+\mathrm{F}_{\text {oats }}^{\text {beef }} * \mathrm{RTF}_{\text {oats }}\right) * \mathrm{C}_{\text {beef }}, \\
& \sum_{\text {pork }}=\mathrm{F}_{\text {barley }}^{\text {pork }} * \mathrm{RTF}_{\text {barley }} * \mathrm{C}_{\text {pork }}, \\
& \sum_{\text {poultry }}=\left(\mathrm{F}_{\text {barley }}^{\text {poulty }} * \mathrm{RTF}_{\text {barley }}+\mathrm{F}_{\text {oats }}^{\text {poultry }} * \mathrm{RTF}_{\text {oats }}+\mathrm{F}_{\text {rye }}^{\text {poultry }} * \mathrm{RTF}_{\text {rye }}+\mathrm{F}_{\text {wheat }}^{\text {poulty }} * \mathrm{RTF}_{\text {wheat }}\right) * \mathrm{C}_{\text {poultry }}, \\
& \sum_{\text {eggs }}=\left(\mathrm{F}_{\text {barley }}^{\text {eggs }} * \mathrm{RTF}_{\text {barley }}+\mathrm{F}_{\text {oats }}^{\text {eggs }} * \mathrm{RTF}_{\text {oats }}+\mathrm{F}_{\text {rye }}^{\text {eggs }} * \mathrm{RTF}_{\text {rye }}+\mathrm{F}_{\text {wheat }}^{\text {eggs }} * \mathrm{RTF}_{\text {wheat }}\right) * \mathrm{C}_{\text {eggs }} .
\end{aligned}
$$

It was later realized that the above weighting scheme was inappropriate. One of two other weighting schemes could be used depending on the dominant animal intake subpathways. If the dominant animal feed intake subpathway involved uptake through the roots of the feed plants, a three-way weighting involving the human consumption rates of the different meat products, the intake-to-edible-product transfer factors of the different meat products, and the root uptake transfer factor is appropriate; if not, a two-way weighting involving the human consumption rates of the different meat products, and the intake-to-edible-product transfer factors of the different meat products, is appropriate.

If root uptake is dominant,

$$
\begin{aligned}
& \mathrm{F}_{\text {meat }}=\frac{\sum_{\text {beef }}+\sum_{\text {pork }}+\sum_{\text {poultry }}+\sum_{\text {eggs }}}{\mathrm{RTF}_{\text {fodder }} * \mathrm{C}_{\text {meat }} * \mathrm{IMF}_{\text {meat }}}, \\
& \sum_{\text {beef }}=\left(\mathrm{F}_{\text {pasture }}^{\text {beef }} * \mathrm{RTF}_{\text {pasture }}+\mathrm{F}_{\text {barley }}^{\text {beef }} * \mathrm{RTF}_{\text {barley }}+\mathrm{F}_{\text {oats }}^{\text {beef }} * \mathrm{RTF}_{\text {oats }}\right) * \mathrm{C}_{\text {beef }} * \mathrm{IMF}_{\text {beef }}, \\
& \sum_{\text {pork }}=\mathrm{F}_{\text {barley }}^{\text {pork }} * \mathrm{RTF}_{\text {barley }} * \mathrm{C}_{\text {pork }} * \mathrm{IMF}_{\text {pork }}, \\
& \sum_{\text {poultry }}=\left(\mathrm{F}_{\text {barley }}^{\text {poulty }} * \mathrm{RTF}_{\text {barley }}+\mathrm{F}_{\text {oats }}^{\text {poultry }} * \mathrm{RTF}_{\text {oats }}+\mathrm{F}_{\text {rye }}^{\text {poultry }} * \mathrm{RTF}_{\text {rye }}+\mathrm{F}_{\text {wheat }}^{\text {poultr }} * \mathrm{RTF}_{\text {wheat }}\right) * \mathrm{C}_{\text {poultry }} * \mathrm{IMF}_{\text {poultry }}, \\
& \sum_{\text {cggs }}=\left(\mathrm{F}_{\text {barley }}^{\text {eggs }} * \mathrm{RTF}_{\text {barley }}+\mathrm{F}_{\text {oats }}^{\text {eggs }} * \mathrm{RTF}_{\text {oats }}+\mathrm{F}_{\text {rye }}^{\text {eggs }} * \mathrm{RTF}_{\text {rye }}+\mathrm{F}_{\text {wheat }}^{\text {eggs }} * \mathrm{RTF}_{\text {wheat }}\right) * \mathrm{C}_{\text {eggs }} * \mathrm{IMF}_{\text {eggs }} .
\end{aligned}
$$


If leaf uptake is dominant,

$$
\begin{aligned}
& \mathrm{F}_{\text {meat }}=\frac{\sum_{\text {beef }}+\sum_{\text {pork }}+\sum_{\text {poultry }}+\sum_{\text {eggs }}}{\mathrm{C}_{\text {meat }} * \mathbb{M M F}_{\text {meat }}}, \\
& \sum_{\text {beef }}=\left(\mathrm{F}_{\text {pasture }}^{\text {beef }}+\mathrm{F}_{\text {barley }}^{\text {beef }} *+\mathrm{F}_{\text {oats }}^{\text {beef }}\right) * \mathrm{C}_{\text {beef }} * \mathrm{IMF}_{\text {beef }}, \\
& \sum_{\text {pork }}=\mathrm{F}_{\text {barley }}^{\text {pork }} * \mathrm{C}_{\text {pork }} * \mathrm{IMF}_{\text {pork }}, \\
& \sum_{\text {poultry }}=\left(\mathrm{F}_{\text {barley }}^{\text {poultry }}+\mathrm{F}_{\text {oats }}^{\text {poultry }}+\mathrm{F}_{\text {rye }}^{\text {poultry }}+\mathrm{F}_{\text {wheat }}^{\text {poultry }}\right) * \mathrm{C}_{\text {poultry }} * \mathrm{IMF}_{\text {poultry }}, \\
& \sum_{\text {eggs }}=\left(\mathrm{F}_{\text {barley }}^{\text {eggs }}+\mathrm{F}_{\text {oats }}^{\text {eggs }}+\mathrm{F}_{\text {rye }}^{\text {eggs }}+\mathrm{F}_{\text {wheat }}^{\text {eggs }}\right) * \mathrm{C}_{\text {eggs }} * \mathrm{IMF}_{\text {eggs }} \cdots
\end{aligned}
$$


APPENDIX C:

CALCULATION OF BODY BURDEN 


\section{APPENDIX C:}

\section{CALCULATION OF BODY BURDEN}

The body burden at six monthly intervals from December 31, 1986, to December 31, 1990, was estimated by assuming (as RESRAD does) a constant intake of cesium-137 for the six-month period.

Cesium- 137 balance in the body requires that

$$
\mathrm{r}_{\text {int }} \mathrm{dt}-\lambda_{\mathrm{e}} \mathrm{qdt}=\mathrm{dq}
$$

where

$$
\begin{aligned}
& r_{\text {int }}=\text { constant intake rate of Cs- } 137, \\
& t \quad=\text { time, } \\
& l_{e}=\text { effective removal rate of Cs-137 (biological and radioactive), and } \\
& q=\text { total amount of Cs-137 in body. }
\end{aligned}
$$

Rearranging, $\frac{\mathrm{dq}}{\mathrm{dt}}=-\lambda_{\mathrm{e}} \mathrm{q}+\mathrm{r}_{\text {int }}$ and integrating gives $\mathrm{q}=A \mathrm{e}^{-\lambda_{\mathrm{e}} \mathrm{t}}+\frac{\mathrm{r}_{\text {int }}}{\lambda_{\mathrm{e}}}$.

Applying the initial condition, $\mathrm{q}=\mathrm{q}_{\mathrm{o}}$ at $\mathrm{t}=0$ gives,

$$
q=\frac{r_{\text {int }}}{\lambda_{e}}+\left(q_{o}-\frac{r_{\text {int }}}{\lambda_{e}}\right) e^{-\lambda_{e} t} .
$$

Substituting for total body content of cesium-137 in terms of body weight and concentration,

$$
\mathrm{c}=\left[\frac{\mathrm{r}_{\text {int }}}{\lambda_{\mathrm{e}}}+\left(\mathrm{c}_{\mathrm{o}} \mathrm{bw}_{\mathrm{o}}-\frac{\mathrm{r}_{\text {int }}}{\lambda_{\mathrm{e}}}\right) e^{-\lambda_{\mathrm{e}} t}\right] / \mathrm{bw},
$$

where

$\mathrm{c}, \mathrm{c}_{\mathrm{o}}=$ concentration of Cs-137 in body at time $\mathrm{t}$ and time 0 ,

$\mathrm{r}_{\text {int }}=$ constant intake rate of Cs-137,

$\lambda_{\mathrm{e}} \quad=$ effective removal of Cs-137 (biological and radioactive), and

bw, $b_{\mathrm{o}}=$ body weight at time $\mathrm{t}$ and time 0 . 
The age-specific body weight (EPA 1985) and removal rate of cesium-137 (ICRP 1989) used in these calculations are given in Table C.1.

TABLE C.1 Age-Related Body Weight and Effective Half-Life

\begin{tabular}{lcc}
\hline \multicolumn{1}{c}{ Individual } & $\begin{array}{c}\text { Body Weight } \\
(\mathrm{kg})\end{array}$ & $\begin{array}{c}\text { Effective Half-Life } \\
(\mathrm{yr})\end{array}$ \\
\hline Man & 73.7 & 0.00722 \\
Woman & 60.6 & 0.0107 \\
Child, age 10 & 36.2 & 0.0120 \\
Child, age 10.5 & 38.0 & 0.0115 \\
Child, age 11 & 39.7 & 0.0111 \\
Child, age 11.5 & 44.1 & 0.0102 \\
Child, age 12 & 46.8 & 0.00972 \\
Child, age 12.5 & 49.5 & 0.00927 \\
Child, age 13 & 53.0 & 0.00876 \\
Child, age 13.5 & 56.4 & 0.00830 \\
Child, age 14 & 58.8 & 0.00801 \\
\hline
\end{tabular}

\section{REFERENCES FOR APPENDIX C}

U.S. Environmental Protection Agency, 1985, Development of Statistical Distributions or Ranges of Standard Factors Used in Exposure Assessments, EPA/600/8-85/010, Washington, D.C.

International Commission on Radiological Protection, 1989, Age-Dependent Dose to Members of the Public from Intake of Radionuclide: Part 1, ICRP Publication 56, Pergamon Press. 